\title{
Winter fog experiment over the Indo-Gangetic plains of India
}

\author{
Sachin D. Ghude ${ }^{1, *}$, G. S. Bhat ${ }^{2}$, Thara Prabhakaran ${ }^{1}$, R. K. Jenamani ${ }^{3}$, \\ D. M. Chate ${ }^{1}$, P. D. Safai ${ }^{1}$, A. K. Karipot ${ }^{4}$, M. Konwar ${ }^{1}$, Prakash Pithani ${ }^{1}$, \\ V. Sinha ${ }^{5}$, P. S. P. Rao ${ }^{1}$, S. A. Dixit ${ }^{1}$, S. Tiwari ${ }^{1}$, K. Todekar ${ }^{1}$, S. Varpe ${ }^{1}$, \\ A. K. Srivastava ${ }^{1}$, D. S. Bisht ${ }^{1}$, P. Murugavel ${ }^{1}$, Kaushar Ali ${ }^{1}$, Usha Mina ${ }^{6}$, \\ M. Dharua ${ }^{1}$, Y. Jaya Rao ${ }^{1}$, B. Padmakumari ${ }^{1}$, A. Hazra ${ }^{1}$, N. Nigam ${ }^{3}$, U. Shende', \\ D. M. Lal ${ }^{1}$, B. P. Chandra ${ }^{5}$, A. K. Mishra ${ }^{5}$, A. Kumar', H. Hakkim ${ }^{5}$, H. Pawar, \\ P. Acharja ${ }^{1}$, Rachana Kulkarni ${ }^{1}$, C. Subharthi ${ }^{1}$, B. Balaji ${ }^{1}$, M. Varghese $^{1}$, \\ S. Bera ${ }^{1}$ and M. Rajeevan ${ }^{7}$
}

\footnotetext{
${ }^{1}$ Indian Institute of Tropical Meteorology, Pashan, Pune 411 008, India

${ }^{2}$ Indian Institute of Science, Bengaluru 560 012, India

${ }^{3}$ India Meteorological Department, New Delhi 110003 , India

${ }^{4}$ Savitribai Phule Pune University, Pune 411 007, India

${ }^{5}$ Indian Institute of Science Education and Research Mohali, Mohali 140 306, India

${ }^{6}$ Indian Agricultural Research Institute, New Delhi 110 012, India

${ }^{7}$ Ministry of Earth Sciences, Government of India, New Delhi 110003 , India
}

The objectives of the Winter Fog Experiment (WIFEX) over the Indo-Gangetic Plains of India are to develop better now-casting and forecasting of winter fog on various time- and spatial scales. Maximum fog occurrence over northwest India is about 48 days (visibility $<1000 \mathrm{~m}$ ) per year, and it occurs mostly during the December-February time-period. The physical and chemical characteristics of fog, meteorological factors responsible for its genesis, sustenance, intensity and dissipation are poorly understood. Improved understanding on the above aspects is required to develop reliable forecasting models and observational techniques for accurate prediction of the fog events. Extensive sets of comprehensive ground-

Keywords: Aerosols, atmospheric profiles, forecasting, winter fog.

THE presence of heavy and extended period of fog in the northern regions of India is one of the major weather hazards, impacting aviation, road transportation, economy and public life in general. Maximum fog events occur over Northwest India, where on an average about 48 (visibility $<1000 \mathrm{~m}$ ) events are observed per year. AllIndia annual morning poor visibility days (PVDs $<4 \mathrm{~km}$ ) have increased from $6.7 \%$ days in 1961 to $27.3 \%$ days in 2008 (ref. 1). Recent studies on fog in India during the past $10-15$ years have raised significant socio-economic concerns due to increase in frequency, persistence and intensity of fog occurrence over the northern parts of the

*For correspondence. (e-mail: sachinghude@tropmet.res.in) based instrumentation were deployed at the Indira Gandhi International Airport, New Delhi. Major in situ sensors were deployed to measure surface micrometeorological conditions, radiation balance, turbulence, thermodynamical structure of the surface layer, fog droplet and aerosol microphysics, aerosol optical properties, and aerosol and fog water chemistry to describe the complete environmental conditions under which fog develops. In addition, Weather Forecasting Model coupled with chemistry is planned for fog prediction at a spatial resolution of $2 \mathrm{~km}$. The present study provides an introductory overview of the winter fog field campaign with its unique instrumentation.

country $y^{2,3}$. A total of 140 flights were cancelled (in addition, 143 were diverted and 363 were delayed) from the Indira Gandhi International Airport (IGIA), New Delhi causing a loss of Rs 120 million to the aviation sector during the winter period 2013-14 (ref. 4).

Radiation and advection fog are common in the winter season. Studies on fog in India indicate that it forms over varied temporal and spatial scales, and shows significant variability from year to year depending on the combination of local meteorological conditions and synoptic-scale weather systems ${ }^{3,5-7}$. Radiation fog forms generally in the rear sector of a western disturbance (WD) that has an influence on the country during winter, whereas advection fog develops in the forward sector of the $\mathrm{WD}^{8}$. WD causes light to moderate spells of rainfall over the northern region during winter ${ }^{7}$, which advects large amount of moisture into the lower troposphere and further through 
evaporation. In addition, irrigation for winter crops and the irrigation network in this region add significant amount of moisture into the lower atmosphere ${ }^{5}$. As soon as the lower-level ridge line forms over the northern region, it enforces persisting stable (calm winds) and clear atmosphere conditions and lower surface temperature leading to the formation of strong surface-based inversions, which facilitate fog formation and its sustainment in the area ${ }^{2,8}$. The land surface processes and emission sources in the Indo-Gangetic Plains (IGP) region contribute to moisture supply and high concentrations of pollutants $^{9,10}$ which favour the persistence of hazy/foggy conditions for extended periods. Sometimes the fog continues to persist for weeks over a vast area with only partial lifting in the late afternoon. Compared to other areas of the world, fog events observed over northern region of India form rapidly, are largest in coverage area and longest in duration. Combinations of these factors introduce formidable challenges for fog forecasting over the region.

The typical fog conditions are understood to be thick surface fog as the lower atmosphere gets saturated, and some of these conditions are coincident with the largescale advection of moisture. Subsequently, boundary layer processes need to be simulated well so as to describe fog as a near surface cloud. Conventional empirical models/approaches are not accurate ${ }^{11,12}$ and weather prediction models cannot be efficiently incorporated for predicting fog and visibility conditions near the surface $^{13}$. The weather prediction models have to be tested and evaluated for several fog episodes, and suitable sets of physical and chemical parameterization need to be identified in relevance to the situation and location of the study. This is a two-step process where the performance of the meteorology model and the pollution forecast model need to be evaluated systematically. These evaluations need dependable and accurate micrometeorological observations during the fog events. From the meteorological point of view, the stable boundary layer processes are typically not represented well in the meteorology model, which requires mixing. One of the key linkages is between gas phase soluble organic compounds, secondary aerosols and cloud condensation nuclei (CCN). These need to be better parameterized in numerical models. Sensitivity studies carried out by chemistry transport model show that organic compounds, secondary aerosols such as $\mathrm{SO}_{4}^{2-}, \mathrm{NH}_{4}^{+}, \mathrm{NO}_{3}^{-}$and inorganic gaseous precursors such as $\mathrm{SO}_{2}, \mathrm{NO}_{x}$ and $\mathrm{NH}_{3}$ have substantial impact on the fog formation process and microphysical structure of the fog event ${ }^{14}$. Thus, the microphysical processes become important to be predicted by the numerical model.

Studies carried out in India indicate significant interest on fog phenomena ${ }^{2,6,7,15-23}$. There is significant compulsion from air, rail and road transport authorities to know whether a fog will occur during the next $24 \mathrm{~h}$, and if so, what could be its intensity, onset time and dissipation rate. For improving location-based fog monitoring in real time, major airports in North India (e.g. Delhi, Jaipur, Amritsar, Varanasi and Lucknow) have been equipped with runway visual range (RVR) for air traffic operation. Presently, a set of 22 live RVRs provide $15-\mathrm{sec}$ fog updates live to air traffic controller (ATC). In addition, India Meteorological Department (IMD) is issuing nowcasting and forecasting based on synoptic data, satellite maps (INSAT 3-D), and an empirical-based fog prediction system ${ }^{18,24,25}$. Some efforts have also been made to provide forecast using dynamical models ${ }^{26}$. Even though the fog now-cast and forecast issued by IMD are useful, there is scope for further improvement in skill and also to develop models for predicting characteristics of fog, like its intensity and duration.

However, not much progress has been made in understanding of the physical characteristics of fog, factors responsible for its genesis, intensity and rapid thickening of the fog layer over IGP and ultimately to develop reliable models for predicting different characteristics of fog. There has been a lack of detailed collocated observations, including the micrometeorological, radiative, chemical and microphysical aspects to study fog phenomena. The interlinking processes for fog formation, sustainment and its dissipation are not well understood. The role of aerosols as CCN and fog droplet formation need to be understood for accurate representation of fog droplet activation and growth. What kind of near-surface thermodynamical conditions lead to the initiation of a fog event? How is the high aerosol number concentration a prerequisite for fog formation? What processes are responsible for extended-period fog and dissipation of the same? How microphysical aspects are decisive for the fog lifecycle and how does boundary layer dynamics control fog microphysics? What are the key parameters needed for physical parameterization of fog and is there room to improve fog prediction with better physics?

In an effort to gain insight into these questions, the Ministry of Earth Sciences (MoES), Government of India (GoI) has taken up, a multi-institutional initiative to conduct an intensive ground-based measurement campaign at IGIA, to understand different physical and chemical features of fog and factors responsible for its genesis, intensity and duration. Winter fog experiment (WIFEX) was conducted on a pilot mode at IGIA, which will be repeated during the next 3-4 consecutive winter seasons. A field campaign was designed to include simultaneous measurements of surface meteorological conditions, radiation balance, turbulence, thermodynamical structure of the surface layer, droplet and aerosols microphysics, aerosols, fog water chemistry, vertical profile of winds, temperature and humidity to describe the complete environment in which a fog develops. The main objective of this experiment is to study the characteristics and variability of fog events and associated dynamics, thermodynamics and fog microphysics, with the aim to achieve 

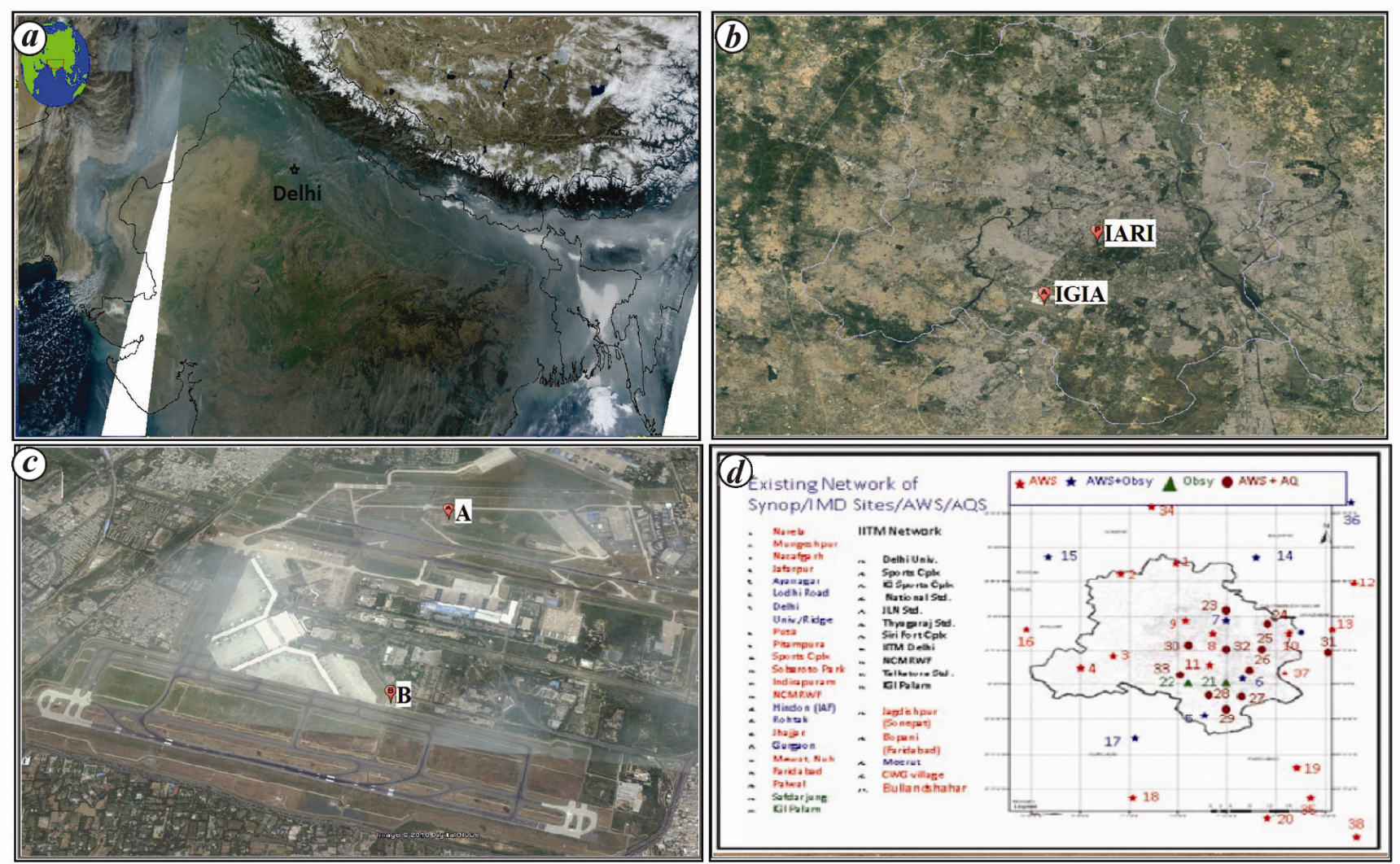

Figure 1. Geographical map of (a) the study region, $(\boldsymbol{b})$ location of fog campaign sites and (c) locations where the observations were taken inside the airport. $(\boldsymbol{d})$ locations of the weather monitoring stations across Delhi.

better understanding of the fog life cycle and ultimately improve capability in fog prediction.

This article provides information on the experimental set-up, instrumentation details and dataset of the twomonth long winter fog field campaign conducted at IGIA. A summary of the preliminary results on physical, chemical and optical properties, microphysics and dynamics of fog observations is also provided.

\section{Fog field campaign and data}

\section{Experimental site}

The winter fog field campaign was conducted at IGIA $\left(28.56^{\circ} \mathrm{N}, 77.09^{\circ} \mathrm{E}\right)$ and Indian Agriculture Research Institute (IARI; $28.63^{\circ} \mathrm{N}, 77.16^{\circ} \mathrm{E}$ ), New Delhi between 15 December 2015 and 15 February 2016. The airport site has a vast open area with frequent formation of fog during the winter season along with the rich spatial observations of visibility across the airport area. Most of the instruments were installed on the northern side of the airport $\sim 400 \mathrm{~m}$ away from the runway (east-west direction), which was less operational during the campaign period. The IARI site, which is located $12 \mathrm{~km}$ away from the air- port in a relatively less built-up area, also has vast open area with frequent fog formation; however it has more vegetation cover. The IARI site is characterized by irrigated agricultural field about $1 \mathrm{~km}$ in radius and surrounded by densely populated residential area (Figure 1). In addition, Delhi has a network of automatic weather stations $(\sim 37)$, air-pollution monitoring network $(\sim 12)$ and operational radiosonde stations of IMD. Figure 1 shows the geographical map of the region with locations of the fog campaign sites and weather stations across Delhi metropolitan area.

\section{Experimental set-up}

A set of in situ and remote sensing instruments were deployed at IGIA and IARI campus from four Indian research/educational institutions: Indian Institute of Tropical Meteorology, Pune; IMD, Delhi; Indian Institute of Science Education and Research (IISER), Mohali, and IARI, Delhi. The instruments deployed fall into the following categories: ground and surface properties, surface layer meteorology, atmospheric profiles, microphysical parameters, radiation, and aerosol and fog chemical and optical properties. The aim of such a combination was to 
RESEARCH ARTICLES

Table 1. Instruments deployed during Delhi winter fog campaign, parameters that can be retrieved from their measurements, instrument range (vertical range, spectral range as relevant), and resolution, and location (IGIA (A): $20 \mathrm{~m}$ tower, IGIA (B): watch tower $12 \mathrm{~m}$ )

\begin{tabular}{|c|c|c|c|c|}
\hline Category & Instruments & Measured parameters & $\begin{array}{l}\text { Range (RA) and } \\
\text { Resolution (RE) }\end{array}$ & Location \\
\hline \multirow[t]{2}{*}{$\begin{array}{l}\text { Ground and surface } \\
\text { properties }\end{array}$} & $\begin{array}{l}\text { Integrated soil temperature and } \\
\text { moisture probes ( } 5 \mathrm{TM} \text {, Decagon } \\
\text { Devices, Inc., USA) placed at } \\
0,-2,-5,-10,-20,-30,-50 \mathrm{~cm} \text { depths }\end{array}$ & $\begin{array}{l}\text { Soil temperature, volumetric } \\
\text { water content, thermal } \\
\text { conductivity in the ground }\end{array}$ & $\begin{array}{l}\text { RA: } 0-50 \mathrm{~cm} \\
\text { RE: } 1 \mathrm{~min}\end{array}$ & $\begin{array}{l}\text { IGIA, } \\
\text { New Delhi }\end{array}$ \\
\hline & $\begin{array}{l}\text { Heat flux plates (HFP01C, HukseFlux, } \\
\text { USA) placed at }-5 \mathrm{~cm} \text { depth }\end{array}$ & Soil heat flux & $\begin{array}{l}\text { RA: } 0-5 \mathrm{~cm} \\
\text { RE: } 1 \mathrm{~min}\end{array}$ & IGIA (A) \\
\hline \multirow[t]{4}{*}{$\begin{array}{l}\text { Surface layer } \\
\text { meteorology }\end{array}$} & $\begin{array}{l}\text { EC system consisting of fast-response } \\
\text { 3D sonic anemometer-thermometer } \\
\text { (Windmaster Pro, Gill Instruments, } \\
\text { Inc., UK) and a } \mathrm{CO}_{2} / \mathrm{H}_{2} \mathrm{O} \text { infrared } \\
\text { gas analyser (IRGA model: LI-7200 } \\
\text { enclosed path } \mathrm{CO}_{2} / \mathrm{H}_{2} \mathrm{O} \text { analyser, } \\
\text { Licor Inc., USA; on } 20 \text { m tower) }\end{array}$ & $\begin{array}{l}\text { Measurement of surface fluxes } \\
\text { of heat, water vapour, } \\
\text { momentum, } \mathrm{CO}_{2} \text { and } \\
\text { turbulence }\end{array}$ & $\begin{array}{l}\text { RA: } 2.5 \text { and } 12.5 \mathrm{~m} \\
\text { RE: } 10 \mathrm{~Hz} \text {; } \\
30 \text { min averaged fluxes }\end{array}$ & IGIA (A) \\
\hline & $\begin{array}{l}\text { Multi-component weather sensors } \\
\text { (WXT 520, Vaisala Oyj, Finland; } \\
\text { on } 20 \mathrm{~m} \text { tower) }\end{array}$ & $\begin{array}{l}\text { Barometric pressure, } \\
\text { air temperature, relative } \\
\text { humidity }(\mathrm{RH}), \text { wind } \\
\text { speed and direction, } \\
\text { precipitation }\end{array}$ & $\begin{array}{l}\mathrm{RA}: 2,8,12,16,20 \mathrm{~m} \\
\mathrm{RE}: 1 \mathrm{~min}\end{array}$ & IGIA (A) \\
\hline & $\begin{array}{l}\text { Temperature and RH sensor } \\
\text { (HMP 45C Vaisala Oyj, } \\
\text { Finland; On } 20 \text { m tower) }\end{array}$ & $\begin{array}{l}\text { Air temperature and } \mathrm{RH} \\
\text { at different heights }\end{array}$ & $\begin{array}{l}\text { RA: } 1,4,6,10 \mathrm{~m} \\
\text { RE: } 1 \mathrm{~min}\end{array}$ & IGIA (A) \\
\hline & $\begin{array}{l}\text { Fine wire thermocouple } \\
\text { (Chromel-Constantan) temperature } \\
\text { sensor; made inhouse (on } 2 \text { m mast) }\end{array}$ & $\begin{array}{l}\text { Close to surface air } \\
\text { temperature profile }\end{array}$ & $\begin{array}{l}\text { RA: surface to } 1.6 \mathrm{~m} \\
\text { at } 25 \text { levels; } \\
\text { separation between } \\
\text { sensors increasing } \\
\text { with height }\end{array}$ & IGIA (A) \\
\hline \multirow[t]{5}{*}{$\begin{array}{l}\text { Atmospheric } \\
\text { profiles }\end{array}$} & $\begin{array}{l}\text { Wind profiler (Astra Microwave; } \\
\text { on } 15 \mathrm{~m} \text { building) }\end{array}$ & $\begin{array}{l}\text { Detects wind speed and wind } \\
\text { directions at various levels } \\
\text { above ground up to } 8 \mathrm{~km} \\
\text { with } 280 \mathrm{MHz} \text { frequency }\end{array}$ & $\begin{array}{l}\text { RA: } 0-8 \mathrm{~km} \\
\text { RE: } 1 \mathrm{~min}\end{array}$ & IGIA \\
\hline & $\begin{array}{l}\text { SODAR (SFAS-64, Scintec GmbH, } \\
\text { Germany; on } 12 \text { m watch tower) }\end{array}$ & $\begin{array}{l}\text { Profiles of } \mathrm{u}, \mathrm{v} \text { and } \mathrm{w} \\
\text { components of wind and } \\
\text { their standard deviations. } \\
\text { Operating frequency: } \\
2.8-4.5 \mathrm{kHz}\end{array}$ & $\begin{array}{l}\text { RA: } 0-450 \mathrm{~m} \\
\text { RE: } 1 \mathrm{~min}\end{array}$ & IGIA (B) \\
\hline & $\begin{array}{l}\text { Radiometer (MP 3000-A Radiometrics } \\
\text { Corp., USA; on } 12 \text { m watch tower) }\end{array}$ & $\begin{array}{l}\text { Water vapour, temperature, } \\
\text { pressure, } \mathrm{RH}, \\
\text { cloud base height }\end{array}$ & $\begin{array}{l}\text { RA: } 0-10 \mathrm{~km} \\
\text { RE: } 1 \text { min }\end{array}$ & IGIA \\
\hline & $\begin{array}{l}\text { MRR (micro rain radar; Metek GmbH } \\
\text { Germany; on } 15 \mathrm{~m} \text { watch tower) }\end{array}$ & $\begin{array}{l}\text { Measures rain precipitation, } \\
\text { rain intensity, drop size } \\
\text { distribution, falling velocity } \\
\text { frequency }=24 \mathrm{GHz}\end{array}$ & $\begin{array}{l}\text { RA: } 0-3 \mathrm{~km} \\
\mathrm{RE}: 1 \mathrm{~min}\end{array}$ & IGIA (B) \\
\hline & $\begin{array}{l}\text { Tethered sonde balloon with athelometer } \\
\text { and grimm (anasphere) }\end{array}$ & $\begin{array}{l}\text { Wind speed, wind direction, } \\
\text { temperature, humidity, } \\
\text { black carbon (BC) and } \\
\text { boundary layer parameters }\end{array}$ & $\begin{array}{l}\text { RA: } 0-1 \mathrm{~km} \\
\mathrm{RE}: 1 \mathrm{~min}\end{array}$ & $\begin{array}{l}\text { IARI, } \\
\text { New Delhi }\end{array}$ \\
\hline $\begin{array}{l}\text { Aerosol and fog } \\
\text { optical properties }\end{array}$ & Fog sampler No: 2 & Visibility, temperature and RH & $\begin{array}{l}\text { RA: } 0-10 \mathrm{~km} \\
\text { RE: } 1 \mathrm{~min}\end{array}$ & $\begin{array}{l}\text { IGIA, } \\
\text { New Delhi }\end{array}$ \\
\hline
\end{tabular}


RESEARCH ARTICLES

Table 1. (Contd)

\begin{tabular}{|c|c|c|c|c|}
\hline Category & Instruments & Measured parameters & $\begin{array}{l}\text { Range (RA) and } \\
\text { Resolution (RI) }\end{array}$ & Location \\
\hline & $\begin{array}{l}\text { Disdrometer (Drstomet Ltd; } \\
\text { on } 15 \mathrm{~m} \text { watch tower) }\end{array}$ & Drop size distribution & $\begin{array}{l}\text { RA: Surface } \\
\text { RE: } 1 \mathrm{~min}\end{array}$ & IGIA (B) \\
\hline & CCN (Droplet Measurement Tech) & $\begin{array}{l}\text { Measures cloud condensed } \\
\text { nuclei particles in the } \\
\text { wavelength range } 0-75 \mathrm{~nm}\end{array}$ & $\begin{array}{l}\text { RA: Surface } \\
\text { RE: } 1 \text { min }\end{array}$ & IGIA (B) \\
\hline \multirow[t]{15}{*}{$\begin{array}{l}\text { Aerosol and fog } \\
\text { optical properties }\end{array}$} & NG athelometer (Maggi Scientific) & $\begin{array}{l}\text { BC mass and absorption } \\
\text { coefficient }\end{array}$ & $\begin{array}{l}\text { RA: Surface } \\
\text { RE: } 1 \text { min }\end{array}$ & IGIA (B) \\
\hline & $\begin{array}{l}\text { MCPC (mixing condensed } \\
\text { particle counter) }\end{array}$ & Size of airborne particles & $\begin{array}{l}\text { RA: Surface } \\
\text { RE: } 1 \text { min }\end{array}$ & IGIA (B) \\
\hline & Nephelometer (Ecotech) & $\begin{array}{l}\text { Scattering coefficient } \\
450,550,700 \mathrm{~nm}\end{array}$ & $\begin{array}{l}\text { RA: Surface } \\
\text { RE: } 1 \mathrm{~min}\end{array}$ & IGIA (B) \\
\hline & $\mathrm{NH}_{3}$ analyser (Tiger Optics) & $\begin{array}{l}\text { Concentration of atmospheric } \\
\text { ammonia }\end{array}$ & $\begin{array}{l}\text { RA: Surface } \\
\text { RE: } 1 \text { min }\end{array}$ & $\operatorname{IGIA}(\mathrm{B})$ \\
\hline & $\mathrm{SO}_{2}$ analyser $($ Ecotech $)$ & $\begin{array}{l}\text { Concentration of atmospheric } \\
\text { sulphur dioxide }\end{array}$ & $\begin{array}{l}\text { RA: Surface } \\
\text { RE: } 1 \text { min }\end{array}$ & IGIA (B) \\
\hline & OC EC sampler (Envirotech) & $\begin{array}{l}\text { Measures organic and } \\
\text { elementary carbon in aerosols }\end{array}$ & $\begin{array}{l}\text { RA: Surface } \\
\text { RE: } 4 \mathrm{~h}\end{array}$ & $\operatorname{IGIA}(\mathrm{A})$ \\
\hline & $\mathrm{PM}_{2.5}$ Sampler & $\mathrm{PM}_{2.5}$, chemical composition & $\begin{array}{l}\text { RA: Surface } \\
\text { RE: } 4 \mathrm{~h}\end{array}$ & IGIA \\
\hline & $\mathrm{PM}_{10}$ Sampler & $\mathrm{PM}_{10}$, chemical composition & $\begin{array}{l}\text { RA: Surface } \\
\text { RE: } 6 \mathrm{~h}\end{array}$ & $\begin{array}{l}\text { IARI, } \\
\text { New Delhi }\end{array}$ \\
\hline & $\begin{array}{l}\text { PAX (photo acoustic } \\
\text { extinctiometer) (DMT) }\end{array}$ & $\begin{array}{l}\text { Scattering and absorption } \\
\text { coefficients, SSA, BC mass }\end{array}$ & $\begin{array}{l}\text { RA: Surface } \\
\text { RE: } 1 \mathrm{~min}\end{array}$ & IARI \\
\hline & Athelometer (MEGASCI) & Absorption coefficient, $\mathrm{BC}$ & $\begin{array}{l}\text { RA: Surface } \\
\text { RE: } 1 \mathrm{~min}\end{array}$ & IGIA (B) \\
\hline & GRIMM & $\begin{array}{l}\text { Aerosol particle size and mass } \\
\text { distribution. Optical range } \\
0.3-20 \mathrm{~nm}\end{array}$ & $\begin{array}{l}\text { RA: Surface } \\
\text { RE: } 1 \mathrm{~min}\end{array}$ & IGIA (A) \\
\hline & CDP (cloud droplet probe) & Drop size $2-50 \mu \mathrm{m}$ & $\begin{array}{l}\text { RA: Surface } \\
\text { RE: } 1 \mathrm{~min}\end{array}$ & IGIA (A) \\
\hline & SMPS APS (TSI Devices) & $\begin{array}{l}\text { Size and mass distribution of } \\
\text { particles }(0.3-800 \mathrm{~nm})\end{array}$ & $\begin{array}{l}\text { RA: Surface } \\
\text { RE: } 1 \mathrm{~min}\end{array}$ & IGIA (B) \\
\hline & Total sky imager (TSI) & $\begin{array}{l}\text { Real-time sky images and } \\
\text { fog/cloud fraction }\end{array}$ & RE: 1 min interval & IGIA (B) \\
\hline & PTRMS offline sampling & VOC & $\begin{array}{l}\text { RA: } 0-15 \mathrm{~m} \\
\text { RE: } 3 \text { times per day } \\
\text { after every } 6 \mathrm{~h}\end{array}$ & IGIA (A) \\
\hline
\end{tabular}

measure simultaneously all key processes in fog genesis and lifecycle. Table 1 shows the instruments deployed at both sites. Instruments deployed during winter fog field campaign at IGIA are shown in Figure 2.

Surface layer meteorology, radiation fluxes, ground and surface properties: A $20 \mathrm{~m}$ micrometeorological tower was installed at IGIA (location A in Figure $1 c$ ), and equipped with multi-component weather sensors at five levels, air temperature and humidity sensors at four levels, 2D sonic anemometers at four levels and fourcomponent net radiation sensor at one level. Four compo- nents of radiation fluxes were measured using net radiometer at $2 \mathrm{~m}$ height. Soil temperature and soil moisture were measured at six levels up to $50 \mathrm{~cm}$ depth using an integrated soil moisture-temperature sensor, and soil heat fluxes were measured at $5 \mathrm{~cm}$ below the surface using two heat flux plates for redundancy. In addition, eddy covariance sensors for turbulence and surface flux measurements were set up at 2.5 and $12.5 \mathrm{~m}$. Positioning of the turbulence sensors are based on footprint analysis, considering the site characteristics. This suite of slowand fast-response sensors allows us to characterize complete radiation and surface energy balance at the site. 
Visibility, temperature, and humidity sensors were also installed at IARI. Table 1 provides details of these sensors. Additionally, a small $2 \mathrm{~m}$ mast equipped with 25 closely placed, fast-response thermocouple temperature sensors (Savitribai Phule University, Pune) was installed close to the $20 \mathrm{~m}$ tower. Temperature sensors were placed between the surface and $1.6 \mathrm{~m}$ to measure lifted temperature inversion close to the surface to study the Ramdas layer.

Atmospheric profiles: A mini-SODAR was operated approximately $50 \mathrm{~m}$ away from the micrometeorological tower to profile $u, v$ and $w$ components of wind velocities and their standard deviations up to $500 \mathrm{~m}$, at $15 \mathrm{~min}$ temporal resolution. Due to poor signal-to-noise ratio, measurements are available only up to $200 \mathrm{~m}$ for most periods. Most of the other instruments (Table 1) were installed close to the $20 \mathrm{~m}$ tower, except $1280 \mathrm{MHz}$ UHFwind profiler and microwave radiometer, which were installed at another location (location B in Figure $1 c$ ) to extend measurements of the wind, temperature and humidity profiles up to $10 \mathrm{~km}$. A ground-based microwave radiometer was continuously operated in colocation with the wind profiler during the campaign for observations of vertical profiles of air temperature, water vapour mixing ratio and cloud liquid water. The 35channel microwave radiometer also provides column integrated precipitable water content, cloud liquid water path and cloud base height. We can also get an indication of drizzle and precipitation from the instrument. A tethered balloon equipped with thermodynamic sensors was operated at this site during nocturnal periods as part of the intensive field campaign (from 9 pm to 9 am IST) to monitor vertical thermodynamic structure up to $1000 \mathrm{~m}$. Measurements on the thermodynamic structure were also carried out by IMD at a site about $10 \mathrm{~km}$ away from the IARI site, using radiosonde profiles routinely at 0000 and 1200 IST.

Aerosol, and fog chemical and optical properties: Visibility at 1 min resolution was monitored inside the airport area using visibility meter on fog sampler and the RVR system of IMD installed at each runway, which was approximately $100 \mathrm{~m}$ from the detailed observational setup. Fog presence was monitored using satellite maps from fog detection algorithm developed for INSAT 3D satellite joint ISRO (Indian Space Research Organization)-IMD initiative. From ground-based instrument, fog presence was also monitored using total sky imager (TSI) installed at the airport. TSI gives real-time sky images from which fog/cloud fraction is computed. Fog droplet size distribution $(2-50 \mu \mathrm{m})$ and liquid water content (LWC) were monitored at $3 \mathrm{~m}$ by a cloud droplet probe (CDP; Droplet Measurement Technologies, Inc.) used for airborne observations of CAIPEEX, which was modified with an aspirator for ground-based operations.
For characterizing absorption and scattering properties of the aerosols, aethalometer, nephelometer and photoacoustic extinctiometer (PAX) were deployed to collect data at $1 \mathrm{~min}$ interval. Filter sampling was done at every $6 \mathrm{~h}$ to analyse the presence of aerosol chemical properties, including metals, dust, black carbon (BC), organic carbon, and hydrophilic and hydrophobic particles. Ambient concentrations of sulphur dioxide $\left(\mathrm{SO}_{2}\right)$ and ammonia $\left(\mathrm{NH}_{3}\right)$ were monitored at the $1 \mathrm{~min}$ intervals. Speciation of volatile organic compounds (VOCs) was performed at the surface, 10 and $20 \mathrm{~m}$ sampling heights three times in a day before, during and after the fog events. Samples were collected for the dense fog cases (visibility $<50 \mathrm{~m}$ ) to analyse the chemical characteristics of fog water, including isotopic analysis. Other measurements on aerosol properties include mixing condensation particle counter (MCDP), aerosol particle number and mass size distribution $(0.23-20 \mu \mathrm{m}$, SMPS: $0.3-800 \mathrm{~nm})$. A CCN counter was installed to measure the number concentration of $\mathrm{CCN}$.

\section{Results}

\section{Fog climatology and trend in Delhi}

Background information on the fog events at Delhi is presented in this section. Table 2 shows monthly climatology of fog occurrence during the winter season (November-February) based on long-term visibility data (1981-2014) archived in IMD from IGIA and Safdarjung Airport. Events were classified as fog and dense fog based on visibility observation below 1000 and $200 \mathrm{~m}$ threshold respectively. The long-term mean indicates that around $60 \%$ (74 days) of all days have fog events and $16 \%$ (20 days) of all days have dense fog events in Delhi during each winter season. Maximum fog and dense fog events are mostly seen in December and January. Figure 3 shows the time series of seasonal (December and January) fog days (hours) from 1981 to 2016 for fog and dense fog events. Although significant inter-annual variability is seen, overall it shows a gradual increase in a number of fog days (hours) over three-decades. Briefly, it indicates that number of fog days has increased from 38 $(\sim 250 \mathrm{~h})$ in the beginning of 1980 s to about 65 in recent years $(\sim 600 \mathrm{~h})$. A similar trend is also seen in easterncentral China and linked to increased urban aerosol loading $^{27}$. The results can be interpreted as an indication of the role of increasing air pollution and humidity ${ }^{2,3}$ to increase fog events over this region. However, we will not explore this aspect further in this article.

\section{Fog events in winter 2015-16}

The climatological conditions experienced during winter fog field campaign included hotter and drier days than 
Table 2. Fog occurrence using longer period visibility data 1981-2014

\begin{tabular}{llcccrr}
\hline Fog at IGIA & & November & December & January & February & Seasonal \\
\hline \multirow{2}{*}{ Fog } & Days & 10 & 24 & 25 & 15 & 74 \\
& Hours & 85 & 246 & 243 & 110 & 684 \\
\multirow{2}{*}{ Dense fog } & Days & 1 & 6 & 10 & 3 & 20 \\
& Hours & 2 & 34 & 52 & 11 & 99 \\
\hline
\end{tabular}

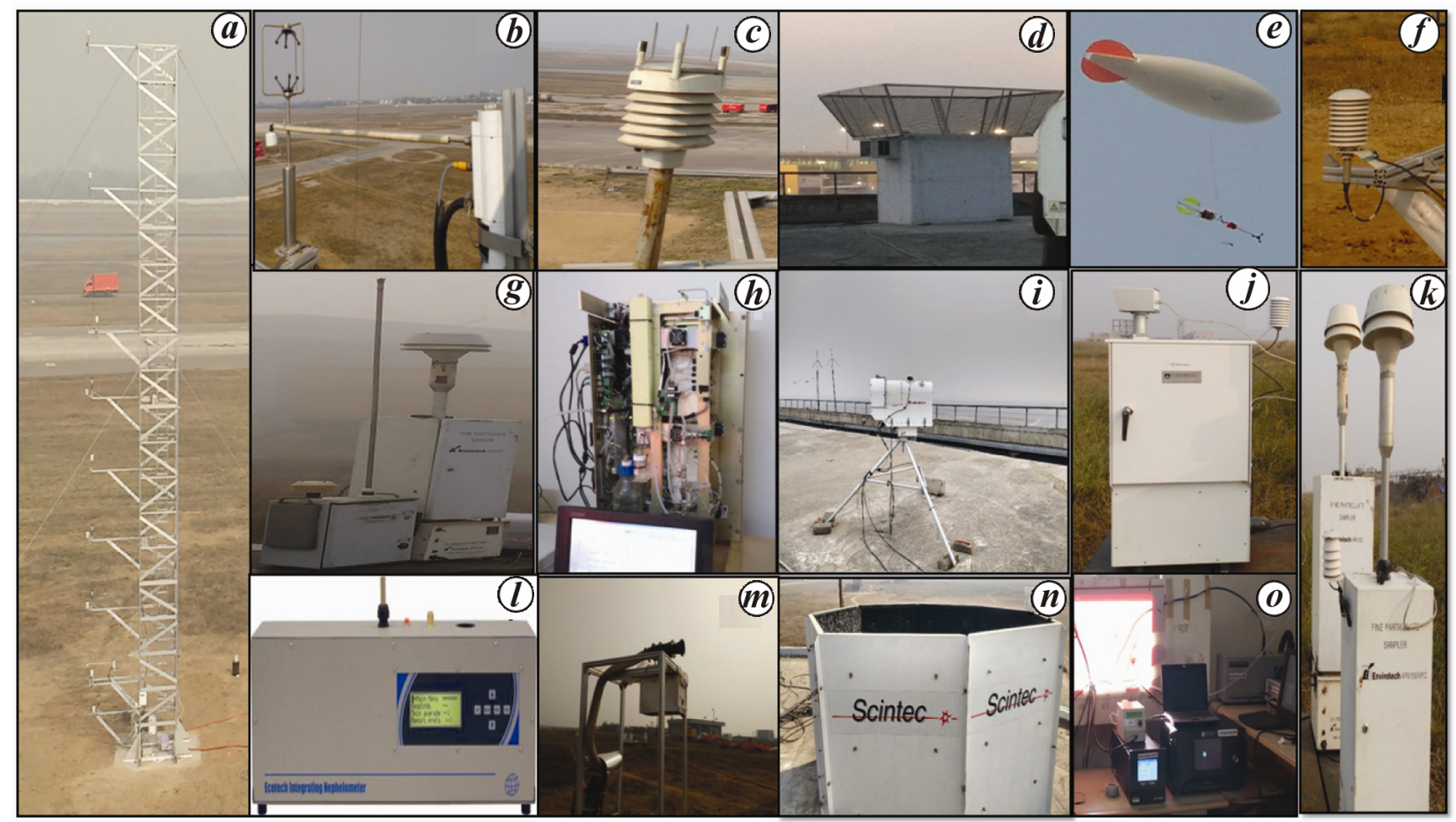

Figure 2. Instruments deployed during winter fog field campaign at Indira Gandhi International Airport (IGIA), New Delhi: $\boldsymbol{a}$, 20 m eddy covariance flux tower; $\boldsymbol{b}$, Eddy covariance system; $\boldsymbol{c}$, All-in-one weather sensor; $\boldsymbol{d}$, Wind profiler; $\boldsymbol{e}$, Tethered sonde balloon; $\boldsymbol{f}$, Gill wind sensors; $\boldsymbol{g}$, GRIMM; $\boldsymbol{h}, \mathrm{CCN}$ counter; $\boldsymbol{i}$, Microwave radiometer profiler; $\boldsymbol{j}$, Fog collector; $\boldsymbol{k}, \mathrm{PM}_{10}$ and PM $\mathrm{PM}_{2.5}$ samplers; $\boldsymbol{l}$, Nephelometer; $\boldsymbol{m}$, CDP with aspirator; $\boldsymbol{n}, \mathrm{SODAR} ; \boldsymbol{o}$, Aethelometer, $\mathrm{NH}_{4}$ analyser and MCPC.

average winter with almost negligible dense fog events in December. In winter 2015-16, mean temperature was above $\sim 5^{\circ} \mathrm{C}$ than normal winter temperature (based on the long-term average) in Delhi. The dense fog events were significantly less in number than the 33-year climatology. However, in January and February, a total of eight dense fog events occurred. Table 3 shows the main characteristics of fog events observed during fog campaign. A significant variability of length, type and intensity of fog was sampled. Most of the dense fog (visibility $<50 \mathrm{~m}$ for more than $3 \mathrm{~h}$ ) events represented an opportunity to sample sufficient fog water for investigating the chemical composition of the dissolved material in fog droplets. Table 3 also indicates the events during which fog water samples were collected.

Out of these eight dense fog events, extremely dense fog events occurred during 21-22 as well as 23-24 January 2016. These events were characterized by very low visibility $(<50 \mathrm{~m})$ for almost $6-8 \mathrm{~h}$, while fog conditions (visibility $<1000 \mathrm{~m}$ ) lasted for a total of about $30 \mathrm{~h}$. In this article we have presented preliminary results of fog events that occurred between 21 and 25 January 2016, particularly the 23 and 24 January fog event as a typical case during the fog campaign.

\section{Key processes involved during fog event: $21-25$ \\ January 2016}

This section presents preliminary results on the temporal evolution of multiple parameters and processes throughout the life cycle of a fog event. MODIS (Terra) satellite images on 23 and 24 January 2016 (Figure 4) clearly indicate thick clouds over the northeastern parts of India extending from Pakistan to eastern Uttar Pradesh. During 23 and 24 January 2016, the synoptic condition was 

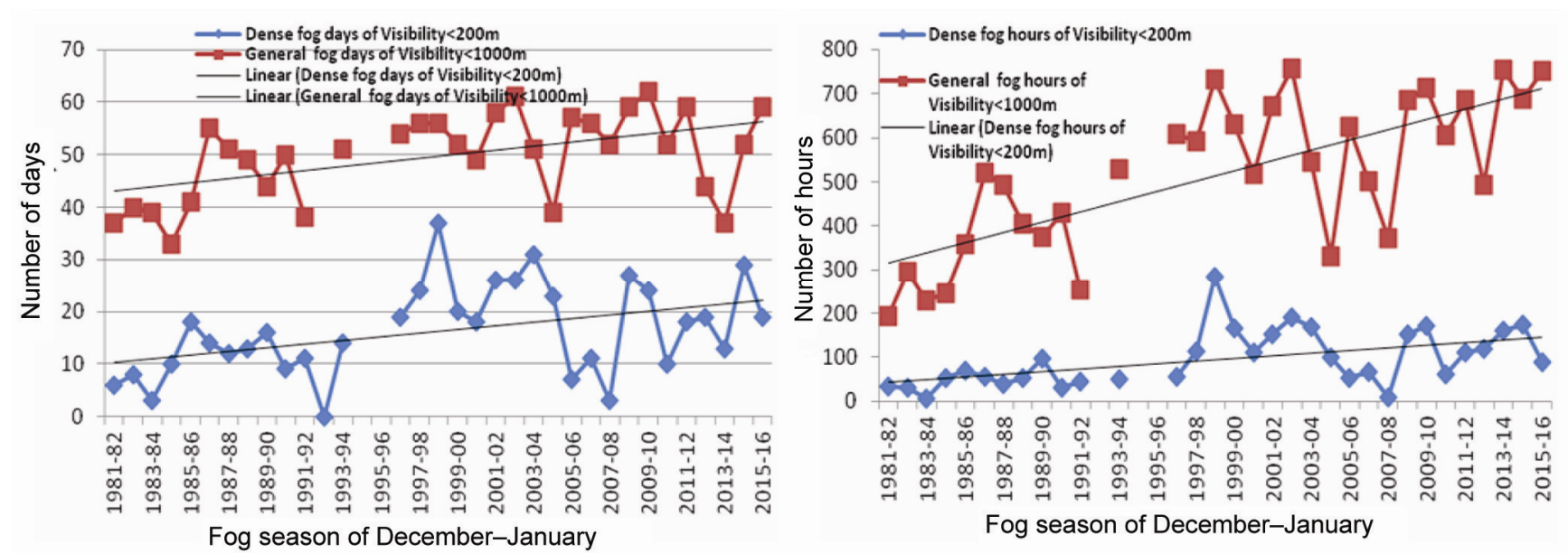

Figure 3. Temporal evolution of seasonal fog (December and January) and dense fog days (left) and hours (right) from 1981 to 2016. Red line shows temporal evolution of visibility conditions for less than $1000 \mathrm{~m}$; blue line shows temporal evolution of visibility less than $200 \mathrm{~m}$ and black line shows the linear fit.

Table 3. Summary of fog events observed during winter fog field campaign at IGIA, with dates, onset time and duration for different visibility thresholds

\begin{tabular}{|c|c|c|c|c|c|c|}
\hline \multirow{2}{*}{ Days } & \multicolumn{6}{|c|}{ Total fog } \\
\hline & \multicolumn{2}{|c|}{$<1000 \mathrm{~m}$ (moderate) } & \multicolumn{2}{|c|}{$<200$ m (dense) } & \multicolumn{2}{|c|}{$<50$ m (very dense) } \\
\hline 22-23 December 2015 & $1300-0800$ & 19 & $0000-0300$ & 03 & Nil & Nil \\
\hline 23-24 December 2015 & $1300-0600$ & 17 & 0100-0300 & 02 & Nil & Nil \\
\hline 24-25 December 2015 & $2000-0300$ & 07 & Nil & Nil & Nil & Nil \\
\hline 26-27 December 2015 & $2200-0100$ & 03 & Nil & Nil & Nil & Nil \\
\hline 07-08 January 2016 & $1200-1100$ & 23 & $2000-0600$ & 10 & $2200-0600$ & 08 \\
\hline 11-12 January 2016 & $2300-0300$ & 04 & Nil & Nil & Nil & Nil \\
\hline 14-15 January 2016 & $1500-0500$ & 14 & $2000-0300$ & 07 & $2000-0200$ & 06 \\
\hline 15-16 January 2016 & $2100-0000$ & 03 & Nil & Nil & Nil & Nil \\
\hline 17-18 January 2016 & $1600-0600$ & 14 & 0000-0500 & 05 & $0200-0400$ & 02 \\
\hline 21-22 January 2016 & $1600-0700$ & 15 & $2100-0500$ & 08 & $2200-0400$ & 06 \\
\hline 23-24 January 2016 & $1600-1000$ & 15 & $2100-0600$ & 09 & $2100-0500$ & 08 \\
\hline 29-30 January 2016 & $2200-0100$ & 03 & Nil & Nil & Nil & Nil \\
\hline 31 January-01 February 2016 & $2200-0500$ & 07 & $0000-0500$ & 05 & $0000-0400$ & 04 \\
\hline 07-08 February 2016 & $2100-0500$ & 07 & $2200-0400$ & 06 & $2200-0300$ & 05 \\
\hline Total fog hours & & $167(46+121)$ & & $61(5+56)$ & & $42(0+42)$ \\
\hline
\end{tabular}

characterized by low wind speed and persistent subsidence of high pressure over a region with a northerly and northwesterly zonal advection supporting cold air advection (see IMD synoptic charts in Figure 4) over the site. The northerly and northwesterly advection affected whole boundary layer and contributed to a net decrease in the temperature field.

Atmospheric profiles: Microwave radiometer was operated at location B of IGIA to measure vertical profiles of air temperature, water vapour mixing ratio and cloud liquid water. The fog layer vertical structure and its associated thermodynamic features can be noted from the microwave radiometer profiler (Figure 5). The equivalent potential temperature $\left(\theta_{\mathrm{E}}\right)$ estimated from radiometer observations is presented for every minute. The features presented in Figure $5 a$ illustrate high $\theta_{\mathrm{E}}$ prior to all fog events, especially it is the highest preceding the onset of fog on the evening of 23 January. The imminent fog could be identified from $\theta_{\mathrm{E}}$ at least $2-3 \mathrm{~h}$ prior to the event. The vertical structure of the fog layer could also be assessed prior to its occurrence with this parameter. These fog events are illustrated in Figure $5 b$ with the cloud liquid density retrieved by the $K$-band of microwave radiometer profiler. It may be noted that the fog layer has a vertical structure and radiometer liquid profile 

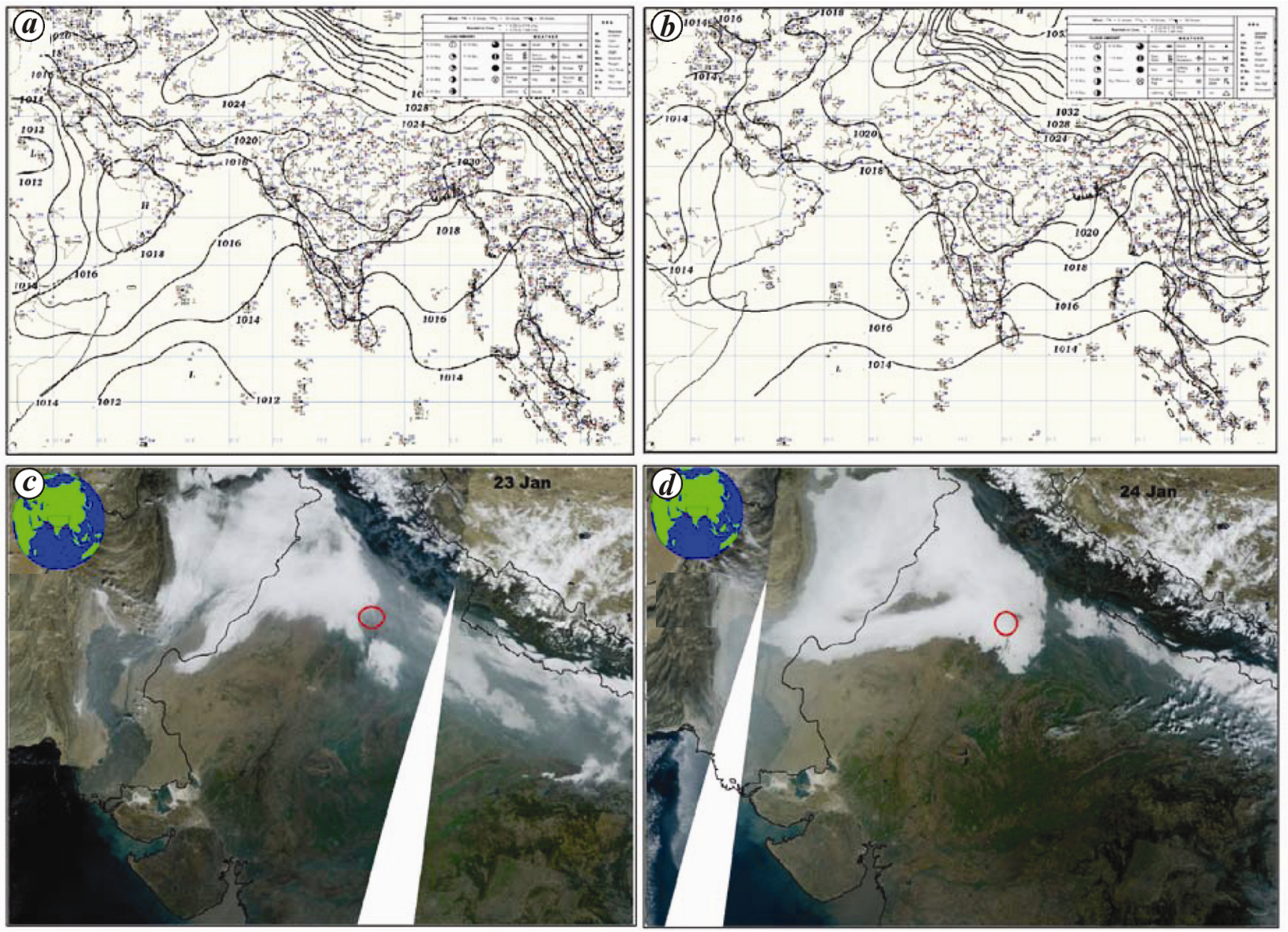

Figure 4. IMD synoptic chart: (a) 23 January 2016 and (b) 24 January 2016. Blanket of fog/shallow clouds over the Indo-Gangetic Plains seen from Terra MODIS on (c) 23 January 2016 and (d) 24 January 2016.

could be used as an indicator for the fog layer thickness and its intensity. The fog layer is eroded from the top (usually $<1 \mathrm{~km}$ ) and also from the surface. As a result, the highest liquid water is noted in the middle of the fog layer. The observations suggest a mini convective boundary layer structure (as may be inferred from the $\theta_{\mathrm{E}}$ profiles), which is sustaining turbulence at the bottom and top of the fog layer. The liquid water profiles may be taken as a qualitative measure to discern the vertical structure of the fog layer; though comparisons with direct measurements are needed. The mid layer humidity present above $3 \mathrm{~km}$ indeed leads to thinner stratus clouds above the fog layer; however, this needs further investigation.

Tethersonde observations taken at the location outside the airport (near IARI) indicated clear deep moist layer up to a height of $300 \mathrm{~m}$, which is persistent throughout the night (Figure 6). Significant variations indicate that the fog layer itself is dynamic and is eroded from the layer above with nearly $20 \%$ humidity. In spite of being dynamic, the moist layer stays deep and extensive. The $\mathrm{BC}$ observations made with the mini-aethalometer using tethered balloon indicated very high mass concentration $\left(>10,000 \mathrm{ng} \mathrm{m}^{-3}\right)$ in the upper layers near $400 \mathrm{~m}$ and more than $20,000 \mathrm{ng} \mathrm{m}^{-3}$ in the lower $200 \mathrm{~m}$. The vertical structure of the thermodynamics thus indeed controls the accumulation of particles in the fog layer. The fog layer top mixing is possibly responsible for the significant dilution below, down to the $200 \mathrm{~m}$ during the tethered balloon observations. High concentrations in the lower layers are attributed to enhanced combustion activity and trapping of particles in the stably stratified layer.

Optical and microphysical properties: Development of fog is defined by a visibility lower than $1000 \mathrm{~m}$ at the surface. Surface visibility evolution at IGIA indicates that fog formation started (visibility $<1000 \mathrm{~m}$ ) on 23 January 2030 IST (Figure 7) and persisted till the next day on 24 January 1100 IST. The dense fog lasted more than $8 \mathrm{~h}$, between 0230 IST (24 January) and 0930 (24 January), with surface visibility reduced from $100 \mathrm{~m}$ to close to zero, indicating very dense fog at IGIA (dense fog regime). Daytime temperature decreased from about $21^{\circ} \mathrm{C}$ (23 January) to about $11^{\circ} \mathrm{C}$ (24 January) after fog initiation 


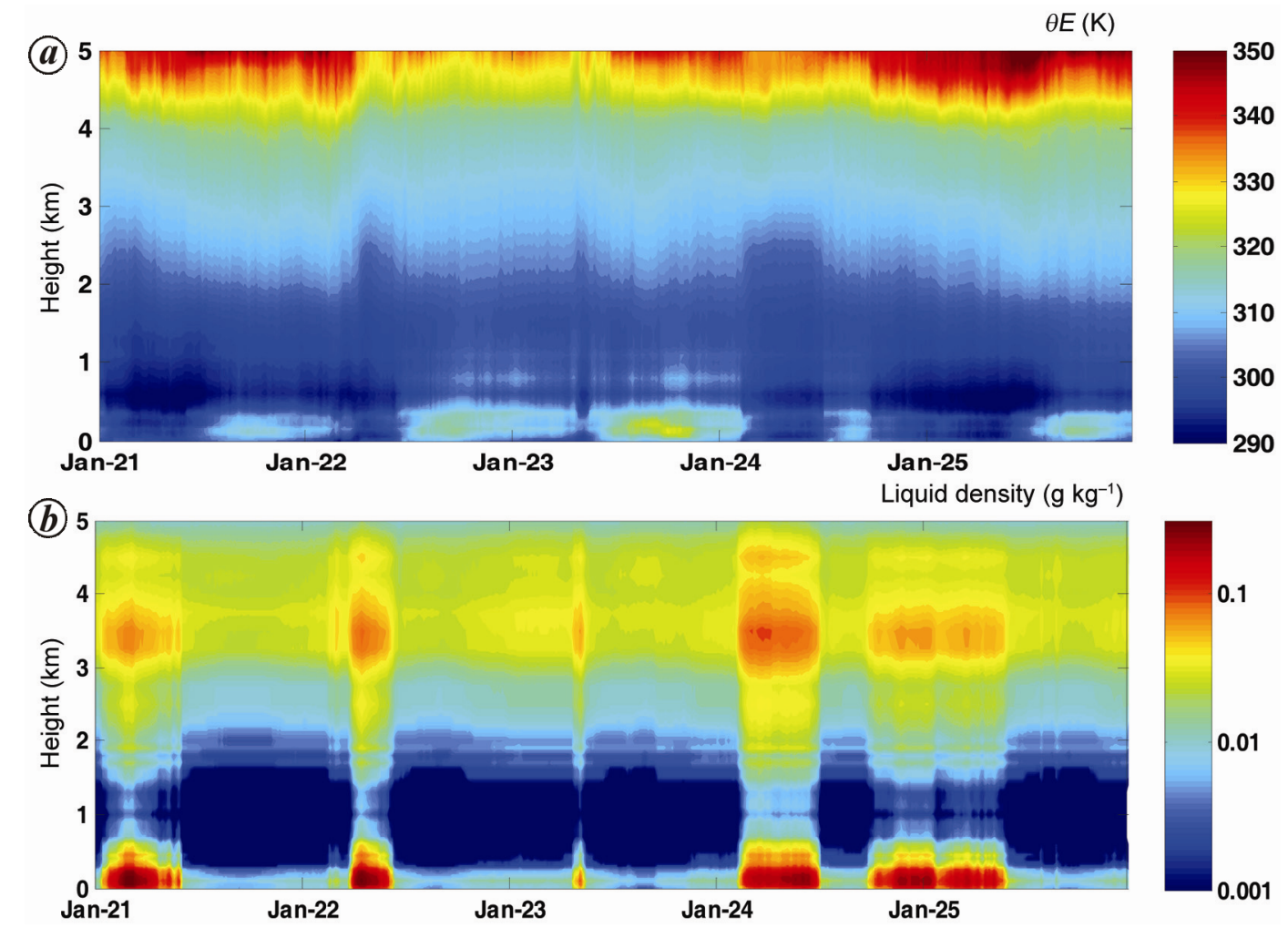

Figure 5. Time-height distribution of radiometer-derived (a) potential temperature $\left(\theta_{E}\right)$ and $(\boldsymbol{b})$ radiometer liquid profiles $\left(\mathrm{g} \mathrm{kg}^{-1}\right)$ during 21-25 January 2016.
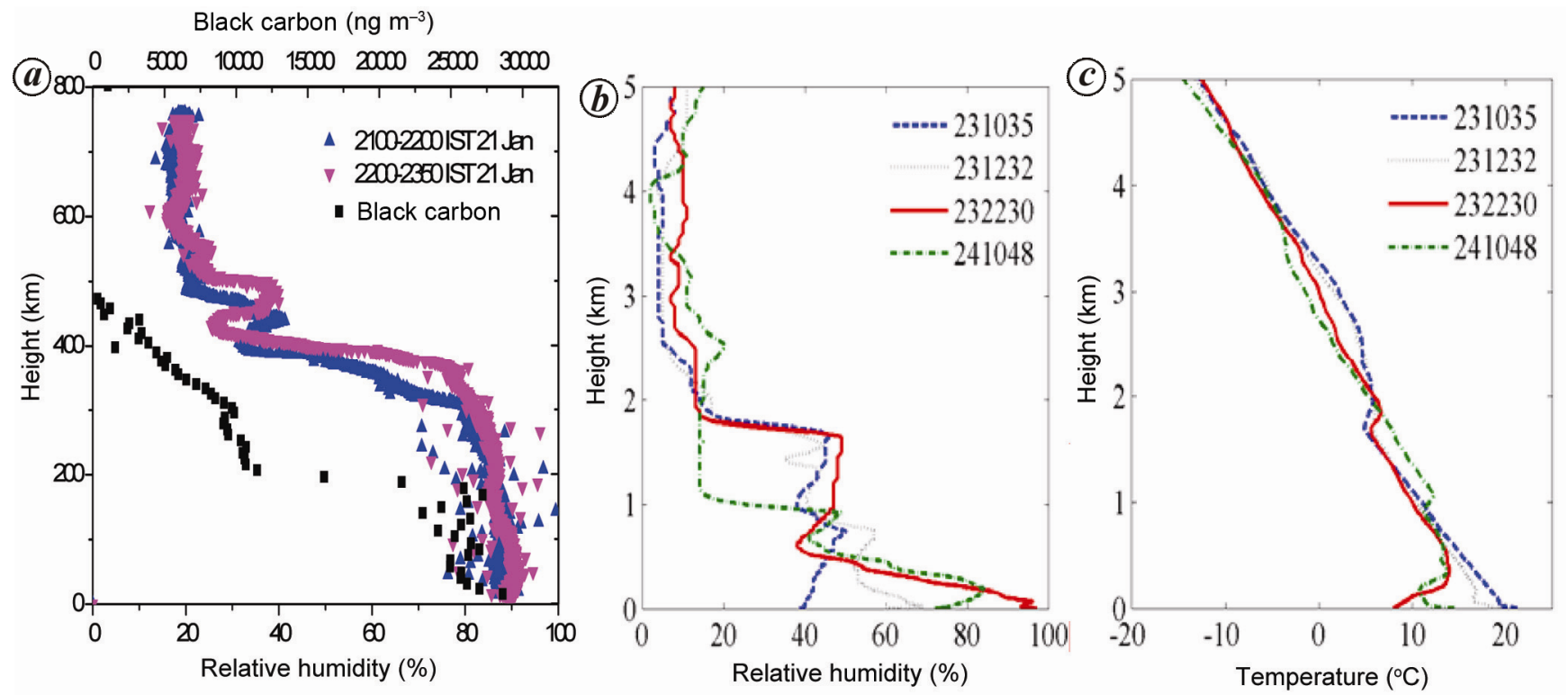

Figure 6. $\boldsymbol{a}$, Tethersonde observations of relative humidity and black carbon mass concentration during the fog event at IARI site. Humidity (b) and temperature profiles $(c)$ from radiosonde measurements in Delhi.

and remained low until the end of the fog event. Time evolution of temperature vertical profiles (Figure $6 c$ ) from radiosonde showed typical inversion layer developed below $700 \mathrm{~m}$ at the midnight (23 January 2230 IST). It can be seen that this event was characterized by hu- midification (Figures $6 b$ and $7 c$ ) in moderate turbulence near the surface. Couple of hours after the fog onset $(23$ January), surface layer became saturated and visibility dropped below $500 \mathrm{~m}$ and prevailed until the next day afternoon. This was also evident from the LWC at CURRENT SCIENCE, VOL. 112, NO. 4, 25 FEBRUARY 2017 


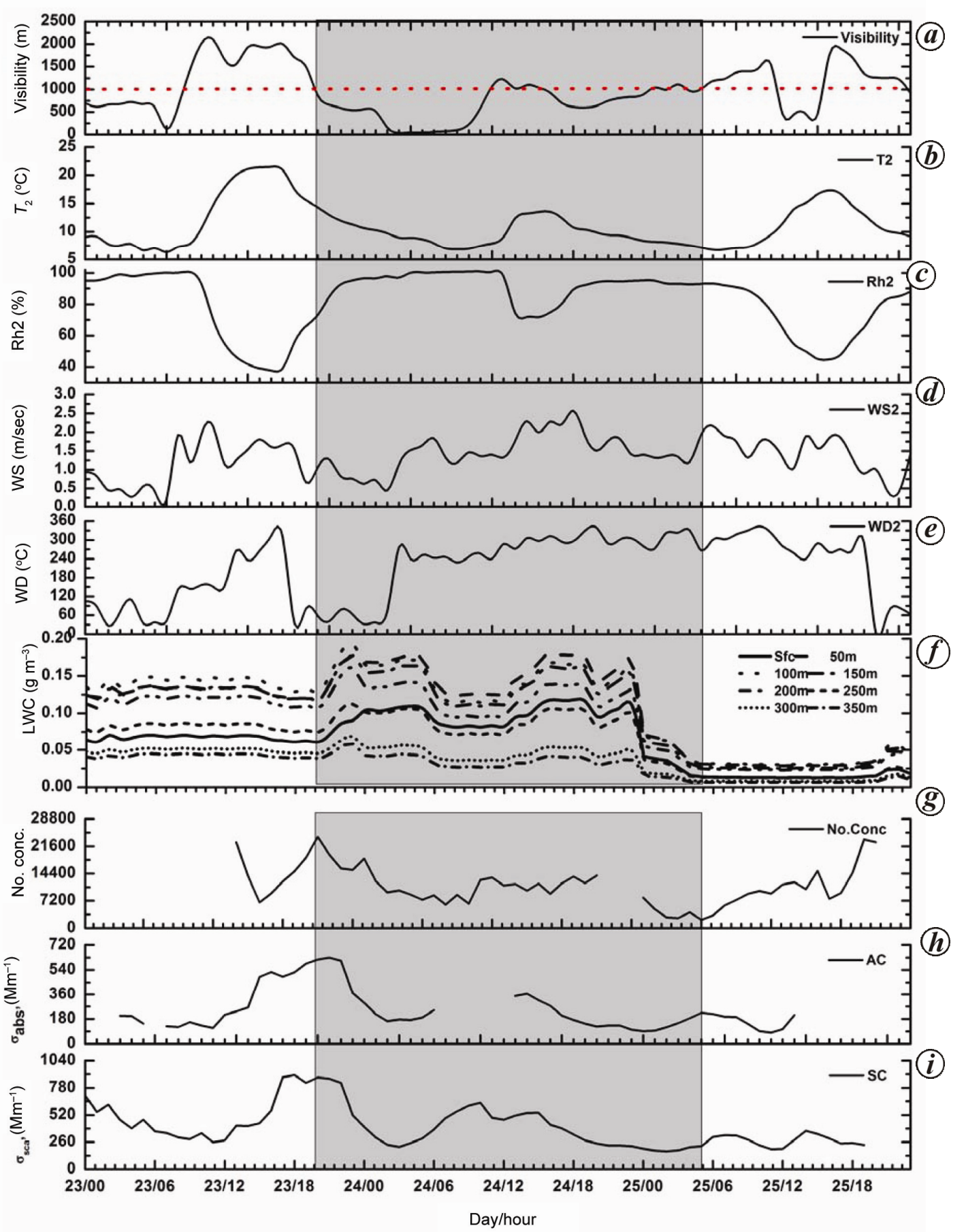

Figure 7. Time series of (a) observed visibility from runway visual range, $(\boldsymbol{b}) 2 \mathrm{~m}$ temperature, $(\boldsymbol{c}) 2 \mathrm{~m}$ relative humidity $(\boldsymbol{d}) 10 \mathrm{~m}$ wind speed, $(\boldsymbol{e}) 10 \mathrm{~m}$ wind direction, $(\boldsymbol{f})$ liquid water content from Microwave Radiometer Profilier (MWRP), $(\boldsymbol{g})$ number concentration from MCPC, $(\boldsymbol{h})$ absorption coefficient, and $(\boldsymbol{i})$ scattering coefficient from nephelometer during 23 January to 25 January 2300 UTC.

various heights obtained from the microwave radiometer profiler from the surface up to $350 \mathrm{~m}$, which showed a sudden increase after the onset, remaining high until the dissipation of the fog in next day morning. Optical properties of aerosol observations (from the nephelometer) showed a sudden increase in both scattering $\left(\sigma_{\mathrm{sca}}\right)$ and absorbing $\left(\sigma_{\mathrm{abs}}\right)$ coefficient immediately after the fog onset, which remained high until the fog was fully developed. This indicates that both scattering aerosols (mainly dust, sulphate and organic compounds) and absorbing aerosols (mainly elemental or BC and hematite dust) were present. In dense fog regime, however, both $\sigma_{\text {sca }}$ and 

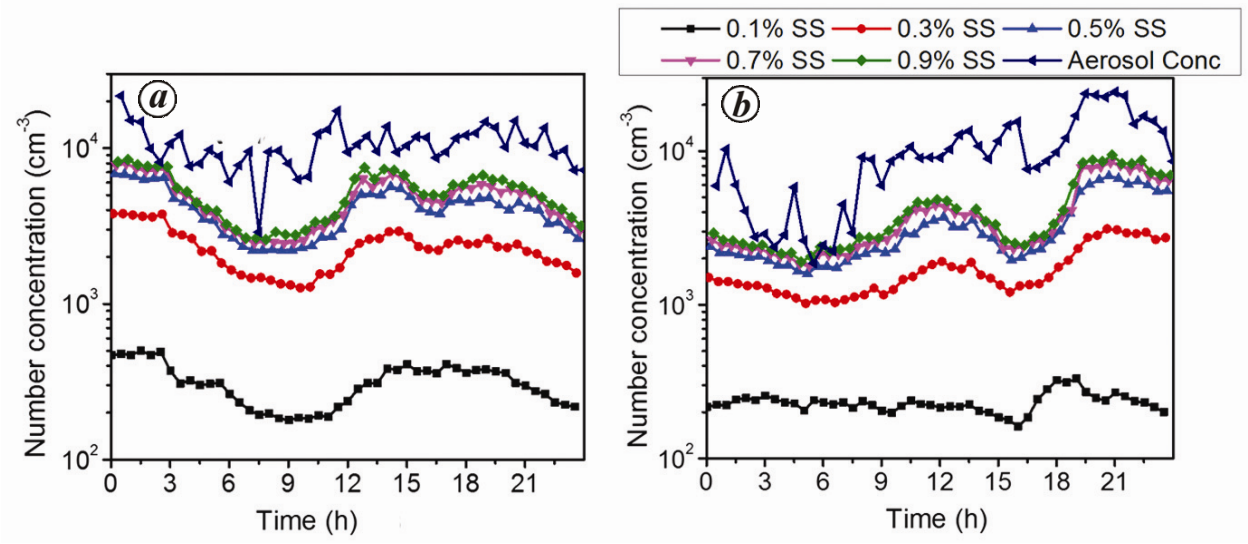

Figure 8. Total condensation particle number concentration and $\mathrm{CCN}$ number concentration at different supersaturations $(0.1 \%, 0.3 \%, 0.5 \%, 0.7 \%$ and $0.9 \%)$ during 24 and 25 January 2016.

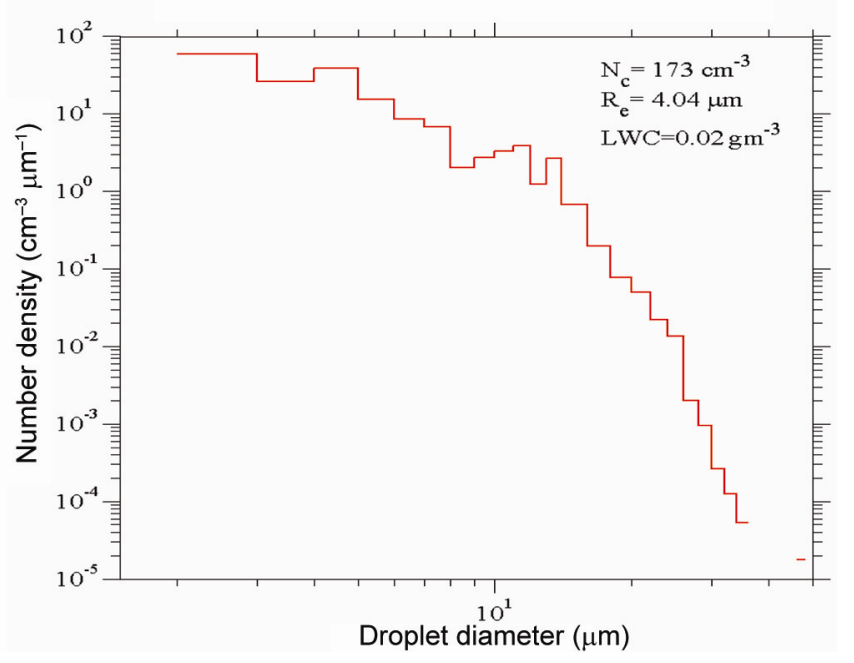

Figure 9. Mean particle size distribution during a fog event on 23 January 2016 from 21:01 to 22:31 UTC at IGI airport.

$\sigma_{\text {abs }}$ dropped to lower values, possibly due to activation of aerosols into fog droplets and collision of aerosols with activated fog droplets.

Around 1100 IST on 24 January, although the temperature was low, humidity decreased to about $70 \%$ and partial dissipation of fog occurred (visibility between 1000 and $1500 \mathrm{~m}$ ), which is also evident by the low LWC during this period. However, in a couple of hours, surface layer became sub-saturated leading to elevated LWC values which dropped visibility again below $1000 \mathrm{~m}$. This low visibility condition (visibility between 750 and $1200 \mathrm{~m}$ ) continued till the next day morning. The fog event ended at 0500 IST on 25 January. The observational site is close to the runway; therefore, there is a constant supply of aerosols from aircraft emissions. Also, Delhi being a highly polluted city ${ }^{28,29}$, there is a constant supply of aerosols due to different anthropogenic activi- ties. Observations of condensation particle count (CPC) indicated values between 2000 and $35,000 \mathrm{~cm}^{-3}$ during all conditions at the measurement location. Some of these may be attributed to aircraft emissions. The stable conditions lead to the trapping of pollutants and aerosol particles in the lower layers. This indicates that under the stable, cold and sub-saturated conditions (humidity greater than $80 \%$ ), initiation of aerosol hydration (not full activation in fog droplets) as haze particles and, to a lesser extent, activation of aerosols in fog droplets ${ }^{30,31}$, might have occurred resulting in quasi-fog/haze conditions following the dense fog. These observations show the complexity of the role of aerosols, suggesting that different processes are at play during various phases of the fog event.

$C C N$ and fog droplet size distribution: Observations of $\mathrm{CCN}$ number concentration at different super-saturations $(0.1 \%, 0.3 \%, 0.5 \%, 0.7 \%$ and $0.9 \%)$ measured at IGIA indicate high counts under foggy conditions (Figure 8). Large increase in $\mathrm{CCN}$ number concentration is observed during the dense fog regime. The diurnal cycle of $\mathrm{CCN}$ was significantly different for 24 January and 25 January (both fog days) from other locations where multiple peaks were noted ${ }^{32}$. However, at the airport location, $\mathrm{CCN}$ activity during the day is largely controlled by the enhanced emissions and by the fog events. The daytime peak coincides with the increase in solar insolation and surface heating. The emissions and enhanced stability during the evening of 25 January could also contribute to increase in the CCN number concentration.

Figure 9 shows an example of mean particle size distribution (PSD) during a fog event on 23 January 2016 from 21:01-22:31 UTC. PSD is observed from a cloud droplet probe (CDP) mounted inside an aspirator. The system was assembled and installed at IGIA during the winter fog campaign. While calculating PSD, a true air speed (TAS) of $15 \mathrm{~ms}^{-1}$ was considered as observed from 


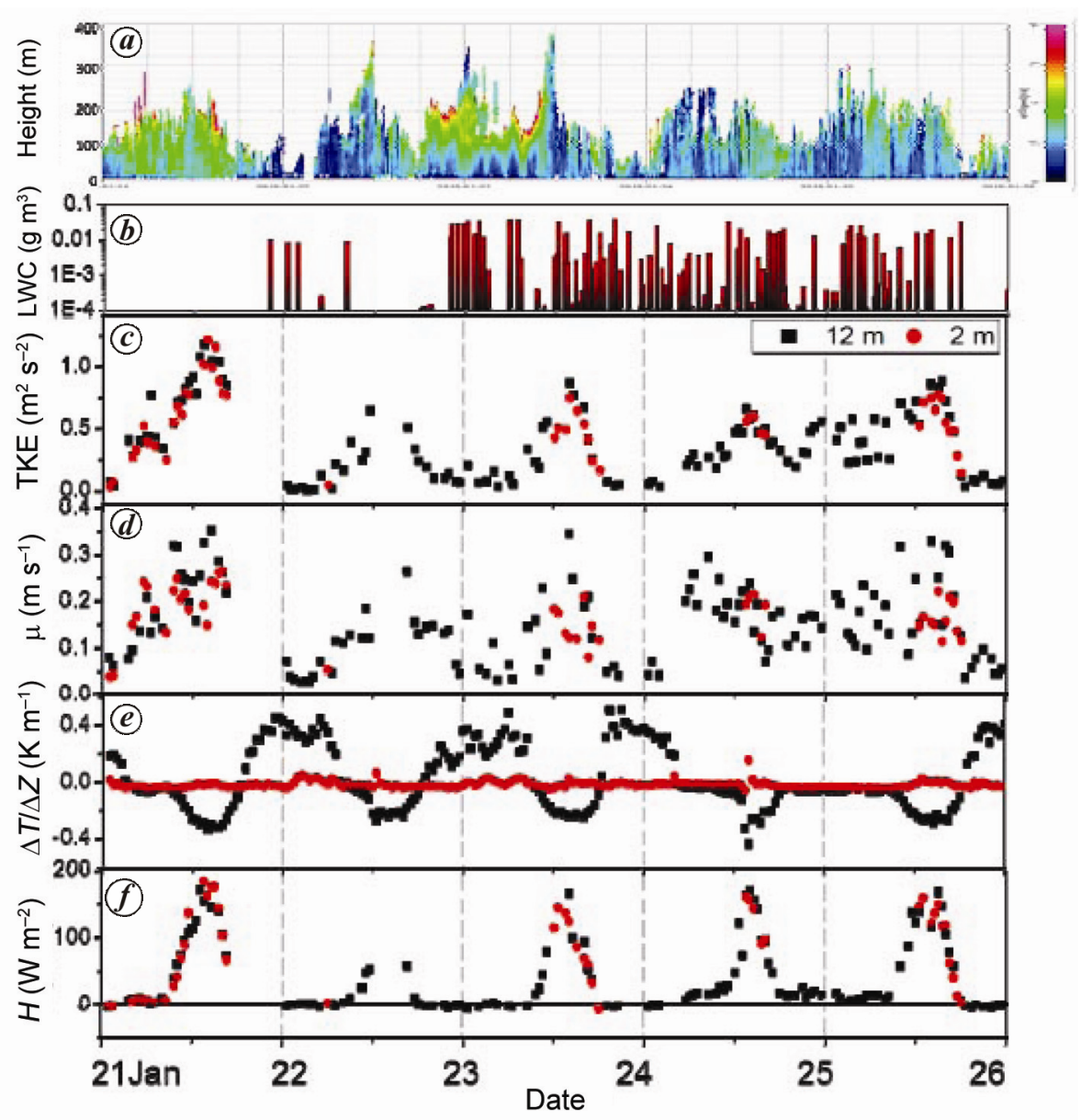

Figure 10. Co-located observations of $(\boldsymbol{a})$ wind profiles from SODAR, $(\boldsymbol{b})$ liquid water content from COP, (c) turbulent kinetic energy (TKE) at 2 and $12 \mathrm{~m}$ level, $(\boldsymbol{d})$ friction velocity, $(\boldsymbol{e})$ temperature gradients between 10 and $16 \mathrm{~m}$ level (red) and temperature gradient between 1 and $4 \mathrm{~m}$ level (black) and $(\boldsymbol{f})$ sensible heat flux at 2 and $12 \mathrm{~m}$.

an anemometer during calm conditions, with the aspirator under operation. The above period was selected as the fog formed in a condition where wind speed was less than $1 \mathrm{~ms}^{-1}$. Note that the size diameter of condensed particles could be less than $D<2 \mu \mathrm{m}$, however, the lower detection limit of the CDP is $2 \mu \mathrm{m}$. PSD is characterized by a broad spectra, where particle concentrations are extended to drop diameter of $D \approx 30 \mu \mathrm{m}$. This suggests that though the concentrations of large particles are less, the present result suggests that very large particles are formed during a dense foggy condition. These large particles may play a significant role in fog dissipation as they can collect other particles in their vicinity and may also evaporate under sub-saturated conditions. We found that the fog particles grew larger and number concentration increased uniformly with time along the entire diameter ranges (not shown here), when the condition changed from the non-foggy to foggy.

Hence, it is most likely that the particles grew larger by vapour deposition/collection processes. Detailed understanding of the evaluation of PSD will be carried out in future considering the thermodynamical and meteorologi- cal conditions. In addition, since the present set-up provides particle concentrations down to $D \approx 2 \mu \mathrm{m}$ only, more observations are required from the combination of different instruments at least to the particle size of $D<2 \mu \mathrm{m}$, to characterize the activation of fog droplets.

Surface layer measurements: In Figure 10, for the surface layer, tower-based observations together with the liquid water derived from CDP probe and wind measurements from SODAR are presented for the surface layer. Different panels in the figure illustrate heat flux derived from the eddy covariance measurements at two levels (2 and $12 \mathrm{~m}$ ), temperature gradients ( 1 and $4 \mathrm{~m}$, and another for 10 and $16 \mathrm{~m}$ levels), friction velocity, turbulent kinetic energy (TKE) at 2 and $12 \mathrm{~m}$ level, LWC from CDP and vertical profiles of wind speed from the SODAR, all from the collocated observations at location A. The heat fluxes at both levels are nearly the same, indicative of the well-mixed conditions. The heat flux becomes weak positive for the fog events and is attributed to surface layer warming due to radiative effects. The radiative cooling near the surface is decisive for the 
formation of the fog layer; however, subsequent longwave radiation interactions would support reducing stability as noted from near-surface gradients in temperature.

Temperature gradient is stronger between 1 and $4 \mathrm{~m}$ level and weak between 10 and $16 \mathrm{~m}$ level (Figure 10). These are indicative of strong stability at lower level. However, the temperature gradient changes significantly and during the fog events on 25 and 26 January, the conditions were neutral or weakly unstable. This is due to long-wave radiative heating and also due to the turbulent mixing. The conditions on 24 January night did not favour such a scenario and the radiative heating due to fog layer did not reduce stability significantly. Mechanical turbulence (with friction velocity and the TKE) plays a decisive role in the sustainment of fog after the fog layer is formed. However, subsequently, TKE acts to dissipate the fog, but a more robust analysis of several events is needed to establish this aspect.

Observations in the roughness sub-layer: Characteristics of the temperature very close to the surface are studied with a special set-up, especially during night-time, with the help of closely spaced temperature profile measurements using fine-wire thermocouples. Figure 11 shows sample profiles from early morning hours of a mostly clear day (23 January) and that with dense fog (25 January). The clear sky morning hours on 23 January show (Figure $11 a$ ) presence of elevated minimum at around $0.05 \mathrm{~m}$ above the surface, with a temperature difference of up to $7^{\circ} \mathrm{C}$ between the surface and the lifted minimum. Air temperature increases sharply above the minimum up to $0.5 \mathrm{~m}$. Occurrence of such elevated minimum and associated Ramdas layer has been reported earlier ${ }^{33}$. The presence of the elevated minimum results in the formation of a very thin unstable layer close to the surface followed by a strong stable lower surface layer above. Close to sunrise, the elevated minimum erodes and later develops into a typical unstable surface layer. The features are different during the dense fog day (24 January, Figure $11 \mathrm{~b}$ ). The behaviour is the same as on 23 January until 02 : 00 LST with the presence of a strong elevated minimum, which changed afterwards. Although there is sharp cooling in the lower few centimetres, air temperatures above the minimum are nearly constant up to $1.6 \mathrm{~m}$, indicating well-mixed conditions. This is due to the radiative effects of fog layer as indicated by the longwave warming. A typical surface layer temperature profile did not develop in the morning after sunrise, due to the persistence of foggy conditions. The role of such roughness sub-layer features on fog life cycle needs to be studied using detailed analyses and focused numerical modelling, and will be dealt separately.

Aerosols and fog water chemical composition: Aerosol and fog water samples were collected at IGIA during the winter fog to examine the chemical composition of aerosols and fog water during major fog events (Figures 12 and 13). Aerosol samples were collected within size fractions of aerodynamic diameter (AD) $<2.5 \mu \mathrm{m}$ (fine mode). Mass concentration determined by gravimetric measurements and chemical analyses of the major aerosol components were performed using the standard sampling and analytical protocols for chemical constituents, e.g. major water-soluble inorganic species $\left(\mathrm{K}^{+}, \mathrm{NH}_{4}^{+}, \mathrm{Na}^{+}\right.$, $\mathrm{Ca}^{2+}, \mathrm{Mg}^{2+}, \mathrm{F}^{-}, \mathrm{Cl}^{-}, \mathrm{NO}_{3}^{-}$and $\left.\mathrm{SO}_{4}^{2-}\right)$. These water-soluble chemical species were shown to represent on average $34 \%$ of total mass of $\mathrm{PM}_{2.5}$, the rest being composed of a carbonaceous material for approximately $60 \%$ and the remaining undetected metallic components. Contribution of positive (cations) and negative (anions) electric charges in the measured composition was $31 \%$ and $71 \%$ respectively. The highest values of chemical species were observed during stable conditions especially during night hours on foggy days ( $11 \%$ higher). Secondary inorganic aerosols (sulphate and nitrate) were the dominant ions $(38 \%)$ in the chemical constituents of the fine particle and were higher during the fog events. The ratio of $\mathrm{NO}_{3}^{-} / \mathrm{SO}_{4}^{2-}$ was found to be 0.63 , which is indicative of dominance of stationary sources over the mobile sources.

A total of eight fog water samples were collected during dense fog events at IGIA, in January and February 2016 using an automatic fog water collector. All the samples were filtered through Whatman-41 filter paper and analysed for $\mathrm{pH}$, conductivity and major ionic components. $\mathrm{pH}$ was measured using digital $\mathrm{pH}$ meter standardized with $\mathrm{pH}$ buffers of 4 and 7 . The anions were measured using ion chromatography (IC) and cations by atomic absorption spectrophotometer (AAS). $\mathrm{NH}_{4}^{+}$was measured using the colorimetric method. However, $\mathrm{HCO}_{3}^{2+}$ was estimated from $\mathrm{pH}$. It was observed that $\mathrm{pH}$ varied between 6.12 and 7.62 with an average of 6.91 , which indicates the alkaline nature of fog water. The ionic conductivity varied from 588 to $1844 \mu \mathrm{S} / \mathrm{cm}$, with an average of $1236 \mu \mathrm{S} / \mathrm{cm}$, which indicates that the fog water is a concentrated solution with pollutants.

Figure 13 shows the average ionic composition of fog water. The concentrations of $\mathrm{NH}_{4}^{+}, \mathrm{SO}_{4}^{2-}, \mathrm{Cl}^{-}, \mathrm{Ca}^{2+}$ and $\mathrm{NO}_{3}^{-}$were found to be very high, indicating that fog water is highly polluted. The ionic composition was found in the order of $\mathrm{NH}_{4}^{+}>\mathrm{SO}_{4}^{2-}>\mathrm{Cl}^{-}>\mathrm{Ca}^{2+}>\mathrm{NO}_{3}^{-}>\mathrm{Na}^{+}>$ $\mathrm{Mg}^{2+}>\mathrm{K}^{+}>\mathrm{F}^{-}>\mathrm{HCO}_{3}^{-}$. Among the anions, concentration of $\mathrm{SO}_{4}^{2-}(3763 \mu \mathrm{eq} / \mathrm{l})$ was maximum, whereas $\mathrm{NH}_{4}$ $(4162 \mu \mathrm{eq} / \mathrm{l})$ showed maximum concentration among the cations. The percentage contributions of various ionic components to the total measured chemical constituents in fog water are also shown in Figure 13 (inset). Maximum contribution was from $\mathrm{NH}_{4}^{+}(28 \%)$ and $\mathrm{SO}_{4}^{2-}(26 \%)$. Ammonium and sulphate are in the form of ammonium sulphate $\left(\left(\mathrm{NH}_{4}\right)_{2} \mathrm{SO}_{4}\right)$. Even though the acidic ions $\mathrm{SO}_{4}^{2-}$ and $\mathrm{NO}_{3}^{-}$are very high, fog water is not acidic because of the very high concentration of neutralizing ions $\mathrm{NH}_{4}^{+}$and 
RESEARCH ARTICLES
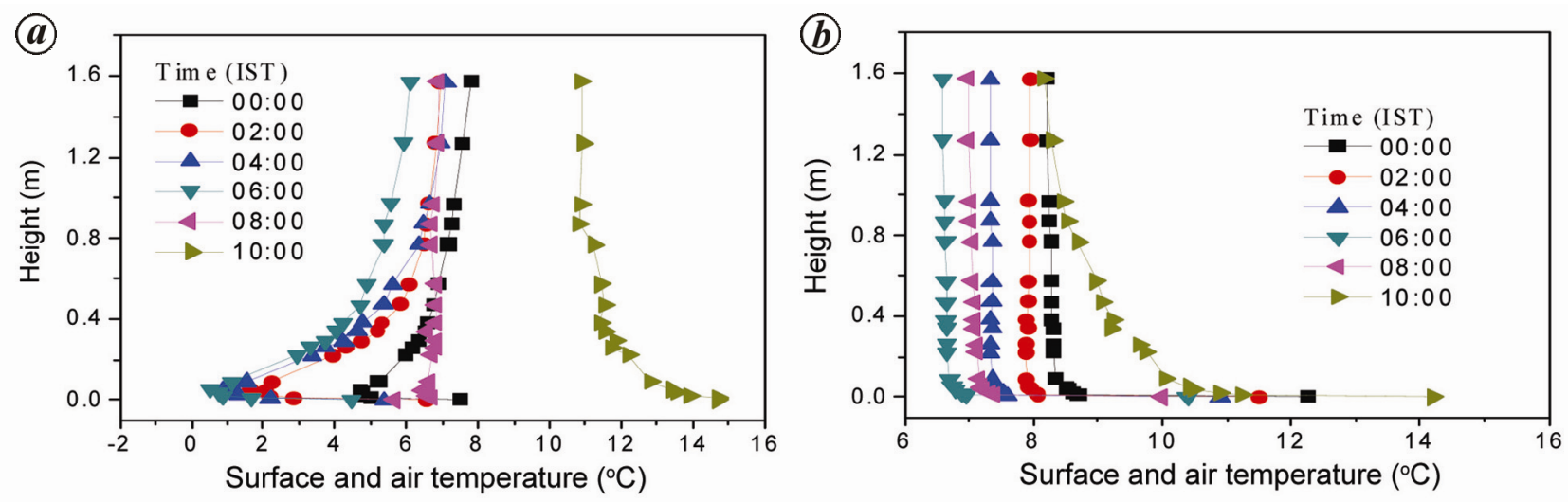

Figure 11. Surface and air temperature profiles measured using fine-wire thermocouples between the surface and $1.6 \mathrm{~m}$ with vertical separation increasing with height. Presented are early morning profiles (a) on a fairly clear day, 23 January 2016 and (b) a foggy day, 25 January 2016.
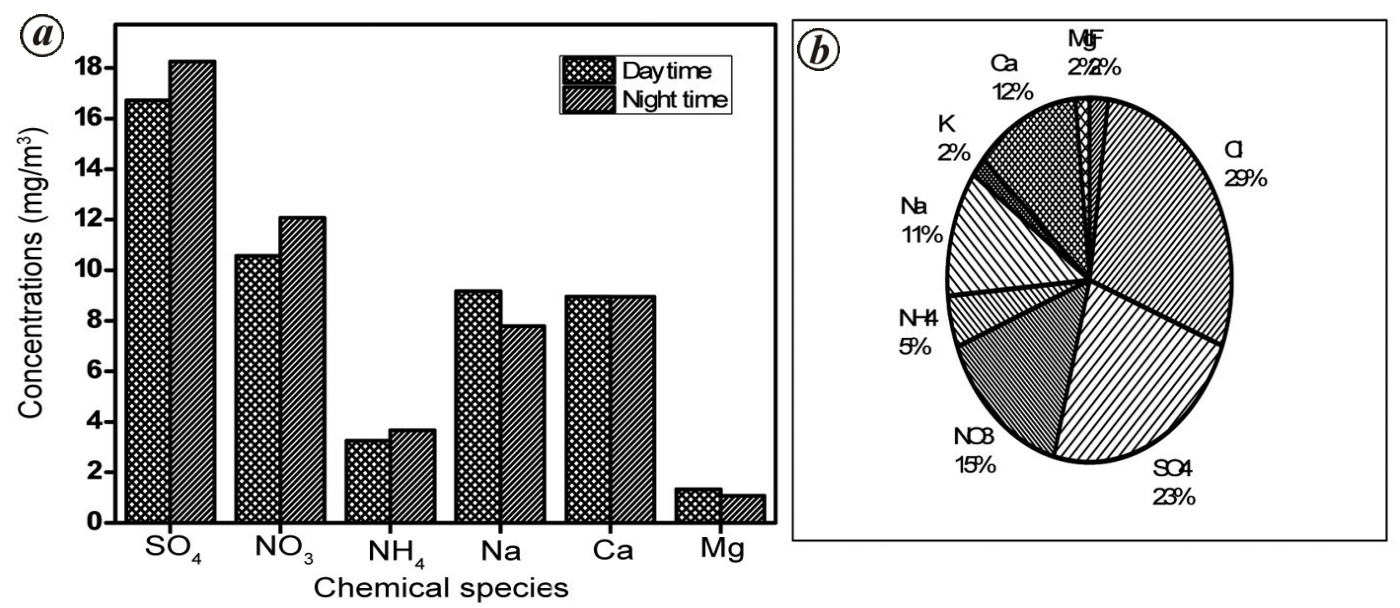

Figure 12. $\boldsymbol{a}$, Contributions (in $\mu \mathrm{g} / \mathrm{m}^{3}$ ) of dominant positive and negative ions in $\mathrm{PM}_{2.5}$. $\boldsymbol{b}$, Percentage contribution of measured chemical constituents in $\mathrm{PM}_{2.5}$ during foggy period over Delhi.

$\mathrm{Ca}^{2+}$ in the samples. The major neutralization was due to $\mathrm{NH}_{4}^{+}$followed by $\mathrm{Ca}^{2+}$. The source identification study indicated that anthropogenic sources $(61 \%)$ dominated over the marine $(21 \%)$ and crustal sources $(18 \%)$. Higher ionic concentrations in fog samples may be due to the combination of aircraft emissions at IGIA and those from other anthropogenic sources present in Delhi. However, further studies are required in the forthcoming winters to confirm the present results on fog water chemistry at Delhi airport.

Volatile organic compounds: Figure 14 summarizes the VOC speciation results for ambient samples collected in the morning, afternoon and night at 10 and $20 \mathrm{~m} \mathrm{sam-}$ pling heights on 19 January 2016. VOCs were collected as whole-air samples and analysed using a highsensitivity proton transfer reaction mass spectrometer (PTR-MS) at the Central Atmospheric Chemistry Facility IISER, Mohali ${ }^{34,35}$. Gaseous VOC mass concentrations ranged from 197 to $472 \mu \mathrm{g} \mathrm{m}^{-3}$, which is rather high for ambient environments and emphasizes that VOCs are important for fog chemistry during the winter season in Delhi. Five important VOCs were quantified for the first time in the ambient air of Delhi during WIFEX. These are isoprene (a very reactive emission from plants and combustion), acetonitrile (a biomass burning tracer) and the oxygenated VOCs - methanol, acetone, acetaldehydewhich are among the most water-soluble organics present in air, and are important for fog water chemistry ${ }^{34,36}$. Among the measured VOCs, the concentration of oxygenated VOCs (sum of methanol, acetaldehyde, acetone, methyl vinyl ketone and methyl ethyl ketone) was found to be highest followed by aromatic compounds (benzene, toluene, the sum of $\mathrm{C} 8$ and $\mathrm{C} 9$ aromatics such as dimethyl and trimethyl benzenes), isoprene and acetonitrile. Benzene has direct health effects on humans due to its carcinogenicity, but in the context of fog is also known to be one of the most efficient secondary organic aerosol precursors present in ambient air. Though hydrophobic when freshly emitted, it can react with hydroxyl 


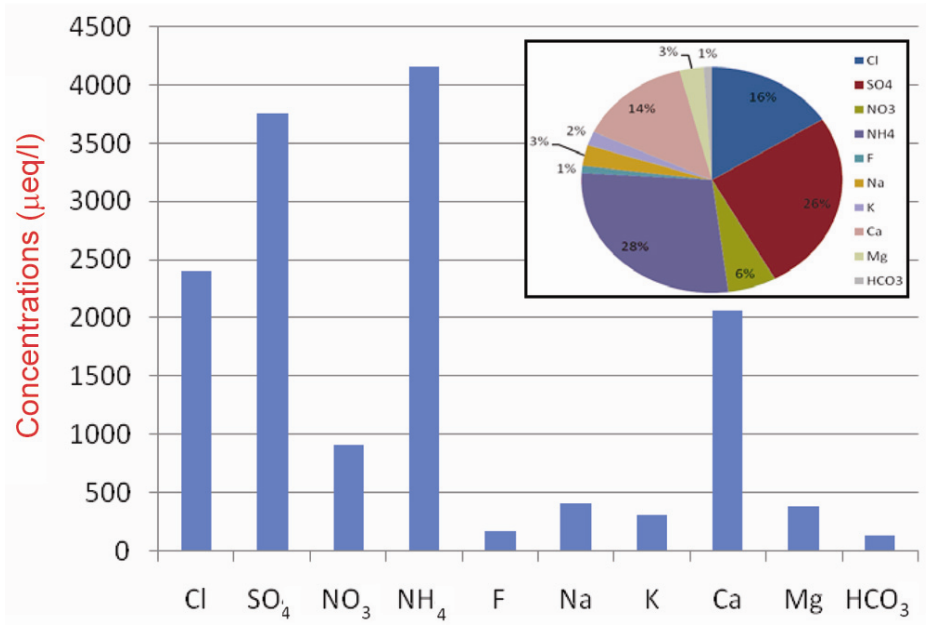

Figure 13. Average concentration of ionic composition of fog water at Delhi for the entire fog episode. (Inset) Percentage contribution of various ionic components in fog water.

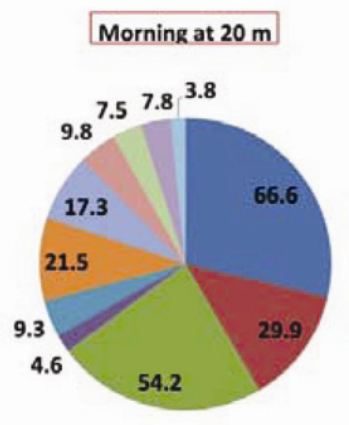

Total $=232.4 \pm 6.5 \mathrm{\mu gm}^{-3}$ Morning at $10 \mathrm{~m}$

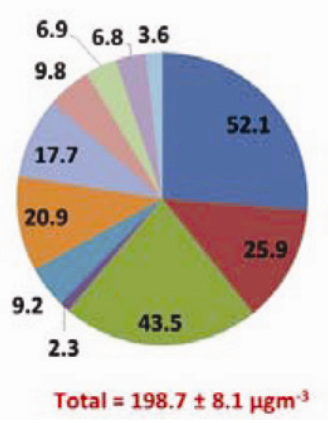

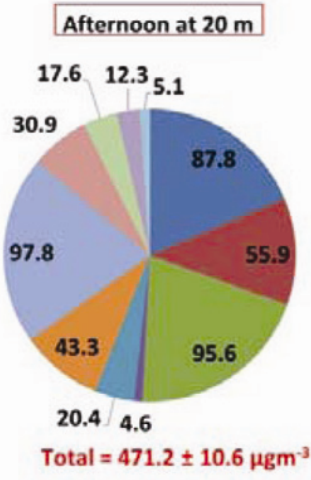
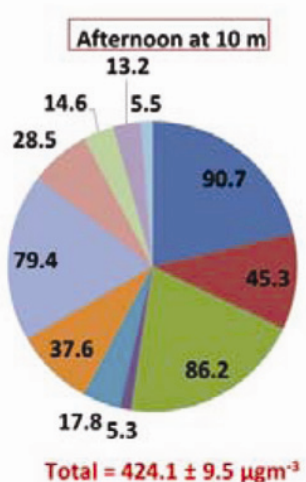

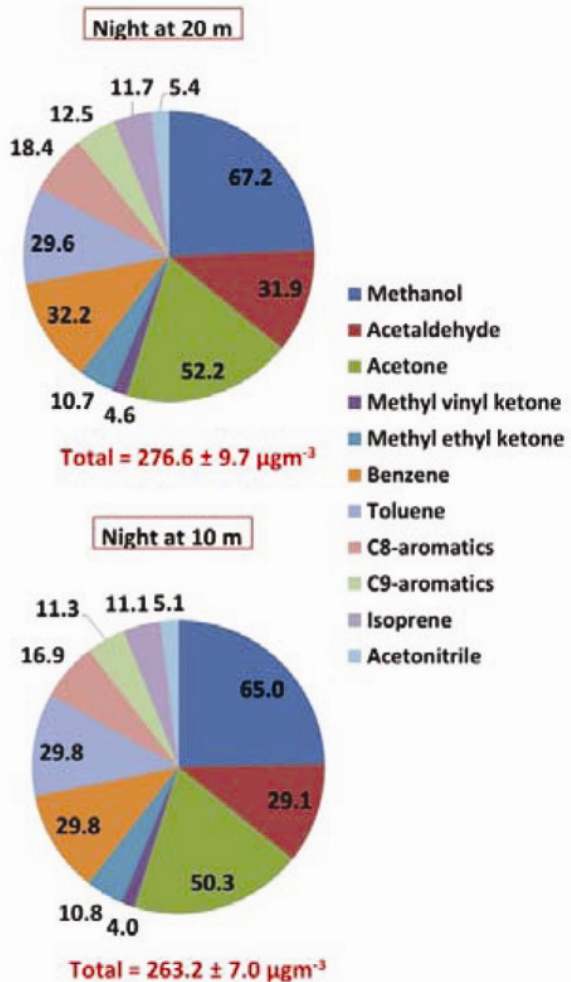

Figure 14. Pie charts summarizing volatile organic compounds (VOC) speciation results for ambient air samples collected at IGI Airport on 19 January 2016 at $20 \mathrm{~m}$ (top panel) and $10 \mathrm{~m}$ (bottom panel) on the site tower. Total mass concentration given below each pie chart represents the total measured VOC mass concentrations $\left(\mu \mathrm{g} \mathrm{m}^{-3}\right) \pm 1$ standard deviation (of the analysis).

radicals in the daytime to photochemically form compounds such as phenols/cresols (hydrophilic) on timescales of a few hours, which can partition to the aerosol phase or coat onto existing aerosol particles thereby altering the water vapour uptake properties of atmospheric aerosol by modifying its chemical composition ${ }^{37}$. A detailed analysis of VOC measurements made during the study is underway and will be communicated soon.

\section{Conclusion}

WIFEX was carried out in the winter season of 2105/16 at IGIA, New Delhi through an initiative taken by MoES, GoI. The main aim of WIFEX was to characterize the fog events occurring in Delhi and monitor simultaneously associated dynamics, thermodynamics, microphysics and chemical composition of the gases, aerosols and fog 
water phases to understand factors responsible for their genesis, intensity and duration. This article provides an overview on the instruments, experimental set-up and summarizes the preliminary results on fog physical, chemical and optical properties, fog droplet size distribution, microphysics and dynamics.

A total of eight dense fog events were sampled during January-February 2016 and analysis for one of the dense fog events that occurred on 23 and 24 January is presented together with detailed data. Analysis of data indicates that the formation of deep inversion, a sudden drop in surface temperature, moderate turbulence, well-mixed surface layer and large humidification (saturated conditions) led to formation of a dense fog on the midnight of 23-24 January 2016.

Major notable results from the observations are as follows: The microwave radiometer profiles of temperature and liquid water indicate a mini-convective boundary layer structure, which sustained turbulence at the bottom and top of the fog layer. Initial results from the radiometer observations also indicate high $\theta_{\mathrm{E}}$ prior to all fog events; imminent fog could be identified with the help of $\theta_{\mathrm{E}}$ at least $2-3 \mathrm{~h}$ prior to the event.

Data from the aerosol and fog water chemistry so far indicate a highly polluted environment in which the fog developed; dominance of combustion and vehicular exhaust sources have also been noted in the aerosol samples. Secondary inorganic aerosols (sulphate and nitrate) were the dominant ions (38\%) in the chemical constituents of fine particles and were higher during the fog events.

The chemical partitioning of fog water samples suggests that $\mathrm{NH}_{4}^{+}(28 \%)$ and $\mathrm{SO}_{4}^{2-}(26 \%)$ dominate the chemical composition. $\mathrm{pH}$ of fog water indicates its alkaline (6.91) nature and $\mathrm{NH}_{4}^{+}$and $\mathrm{Ca}^{+}$were found to be the major neutralizing components.

Mass concentration of gaseous VOCs ranged from 197 to $472 \mu \mathrm{g} \mathrm{m}^{-3}$, which is rather high for ambient environments and emphasizes that VOCs are of great importance in fog chemistry during the winter season. A significant concentration of aromatic VOCs such as benzene was also seen, the photochemical oxidation product of which can alter the water vapour uptake properties of atmospheric aerosols by modifying their chemical composition.

Overall, the detailed observations undertaken and associated model simulation will be used to better understand the winter fog and improve its prediction, by tuning the physical parameterizations and also possibly finding the chains of associations for fog droplet formation. Systematic studies with detailed observations for several fog episodes are necessary to make progress in forecasting these events, their duration and dissipation, etc. It is expected that the data collected during the winter fog field campaign for the next 3-4 years will contribute towards a better understanding of the fog life cycle in different regimes and develop a suitable forecasting system for airports. Data collected during WIFEX will be of wide interest to the scientific community. These data will be made available for scientific research according to the MoES data policy as follows: (i) Scientists involved in WIFEX have priority in the use of their special data in the first year. Individuals/groups/organizations interested in using the data within this period can get them in collaboration mode. (ii) After one year, data will be freely accessible to all participants/individuals/groups/organizations within the limits of the scientific objectives of the project proposed in collaboration mode.

1. Jaswal, A. K., Kumar, N., Prasad, A. K. and Menas, K., Decline in horizontal surface visibility over India (1961-2008) and its association with meteorological variables. Nat. Hazards, 2013, doi:10.1007/s11069-013-0666-2.

2. Jenamani, R. K., Alarming rise in fog and pollution causing a fall in maximum temperature over Delhi. Curr. Sci., 2007, 93, 314322 .

3. Syed, F. S., Kornich, H. and Tjernstrom, M., On the fog variability over South Asia. Climate Dyn., 2012, 39, 2993-3005.

4. Kulkarni, R. G., Wintertime fog in Delhi and its effect on aviation economy. M Sc Project Report Submitted to Savitribai Phule University, Pune, 2016.

5. Badarinath, K. V. S., Shailesh, K. K., Anu Rani, S. and Roy, P. S., Fog over Indo-Gangeticplains - a study using multisatellite data and ground observations. IEEE J. Sel. Top. Appl. Earth Obs. Remote Sensing, 2009, 2(3), 185-195.

6. Pasricha, P. K., Gera, B. S., Shastri, S., Maini, H. K., Ghosh, A. B., Tiwari, M. K. and Garg, S. C., Role of water vapour green house effect in the forecasting of fog occurrence. Boundary-Layer Meteorol., 2003, 107(2), 469-482.

7. Dimri, A. P., Niyogi, D., Barros, A. P., Ridley, J., Mohanty, U. C., Yasunari, T. and Sikka, D. R., Western disturbances: a review. Rev. Geophys., 2015, 53, 225-246; doi:10.1002/2014RG000460

8. Sawaisarje, G. K., Khare, P., Shirke, C. V., Deepakumar, S. and Narkhede, N. M., Study of winter fog over Indian subcontinent: climatoical perspectives. Mausam, 2014, 65(1), 19-28.

9. Kulkarni, P. S., Jain, S. L., Ghude, S. D., Arya, B. C. and Dubey, P. K., On some aspects of tropospheric ozone variability over the Indo-Gangetic (IG) basin, India. Int. J. Remote Sensing, 2009, 30(15-16), 4111-4122.

10. Ghude, S. D., Kulkarni, P. S., Beig, G., Jain, S. L. and Arya, B. C., Global distribution of tropospheric ozone and its precursors: a view from space. Int. J. Remote Sensing, 2010, 31(2), 485-495.

11. Gultepe, I. et al., Fog research: a review of past achievements and future perspectives. Pure Appl. Geophys., 2007, 164, 11211159.

12. Gultepe, I. and Milbrandt, J. A., Probabilistic parameterizations of visibility using observations of rain precipitation rate, relative humidity, and visibility. J. Appl. Meteorol. Climatol., 2010, 39, 36-46.

13. Steeneveld, G. J., Ronda, R. J. and Holtslag, A. A. M., The challenge of forecasting the onset and development of radiation fog using mesoscale atmospheric models. Boundary-Layer Meteorol., 2015, 154, 265-289; doi:10.1007/s10546-014-9973-8

14. Xing-Can and Xue-Liang, Impacts of secondary aerosols on a persistent fog event in Northern China. Atmos. Ocean. Sci. Lett., 2012, 5(5), 401-407.

15. Khemani, L. T., Momin, G. A., Rao, P. S. P., Safai, P. D. and Prakash, P., Influence of alkaline particulates on the chemistry of fog water at Delhi, North India. Water, Air Soil Pollut., 1987, 34, 183-189. 


\section{RESEARCH ARTICLES}

16. Kapoor, R. K., Tiwari, S., Ali, K. and Singh, G., Chemical analysis of fog water at Delhi, North India. Atmos. Environ., 1993, 27, 2453-2455.

17. Ali, K., Momin, G. A., Tiwari, S., Safai, P. D., Chate, D. M. and Rao, P. S. P., Fog and precipitation chemistry at Delhi, North India. Atmos. Environ., 2004, 38, 4215-4222.

18. Bhowmik Roy, S. K., Sud, A. M. and Singh, C., Forecasting fog over Delhi - an objective method. Mausam, 2004, 55(2), 313322 .

19. Singh, C., Unusual long and short spell of fog conditions over Delhi and northern plains of India during December-January 2009-2010. Mausam, 2011, 62(1), 41-50.

20. Singh, J. and Kant, S., Radiation fog over North India during winter from 1989-2004. Mausam, 2006, 57(2), 271-290.

21. Singh, J., Giri, R. K. and Kant, S., Radiation fog viewed by INSAT-1D and Kalpana geostationary satellite. Mausam, 2007, 58(2), 251-260.

22. Suresh, R., Janakiramayya, M. V. and Sukumar, E. R., An account of fog over Chennai. Mausam, 2007, 58(4), 501-512.

23. Jenamani, R. K. and Rathod, L. S., Physical processes from data analysis, real time fog forecast system, performances of various indigenous fog models and benchmarking. Technical Report (FDP-FOG 2008-2015), Meteorological Watch Office, IGI Airport, Delhi, 2015.

24. Chaurasia, S., Sathiyamoorthy, V., Shukla B. P., Simon, B., Joshi, P. C. and Pal, P. K., Night time fog detection using MODIS data over northern India. Meteorol. Appl., 2011, 18(4), 483-494.

25. Ahmed, R., Dey, S. and Mohan, M., A study to improve night time fog detection in the Indo-Gangetic Basin using satellite data and to investigate the connection to aerosols. Meteorol. Appl., 2014, doi: $10.1002 /$ met. 1468

26. Goswami, G. and Tyagi, A., Advance forecasting of onset, duration and hourly fog intensity over Delhi. Research Report No. RR CM 0714, CSIR Centre for Mathematical Modelling and Computer Simulation, Bengaluru, India, 2007.

27. Niu, S. J., Zhao, C. S., Lu, L. J. and Yang, J., Analysis of the microphysical structure of heavy fog using a droplet spectrometer: a case study. Adv. Atmos. Sci., 2010, 27(6), 1259-1275; doi: 10.1007/s00376-010-8192-6

28. Beig, G. et al., Evaluating population exposure to environmental pollutants during Deepavali fireworks displays using air quality measurements of the SAFAR network. Chemosphere, 2013, 92(1), $116-124$.

29. Beig, G. et al., Quantifying the effect of air quality control measures during the 2010 Commonwealth Games at Delhi, India. Atmos. Environ., 2013, 80, 455-463.

30. Noone, K. J. et al., Changes in aerosol size and phase distributions due to physical and chemical processes in fog. Tellus B, 1992, 44, 489-504; doi:10.1034/j.1600-0889.1992.t01-4-00004.x

31. Hammer, E. et al., Investigation of the effective peak supersaturation for liquid-phase clouds at the high-alpine site Jungfraujoch,
Switzerland (3580 m amsl). Atmos. Chem. Phys., 2014, 14, 11231139; doi:10.5194/acp-14-1123-2014

32. Varghese, M. et al., Airborne and ground based CCN spectral characteristics: inferences from CAIPEEX-2011. Atmos. Environ., 2016, 125, 324-336.

33. Narasimha, R., The dynamics of the Ramdas layer. Curr. Sci., 1994, 66, 16-23.

34. Sinha, V., Kumar, V. and Sarkar, C., Chemical composition of pre-monsoon air in the Indo-Gangetic Plain measured using a new PTR-MS and air quality facility: high surface ozone and strong influence of biomass burning. Atmos. Chem. Phys., 2014, 14, 5921-5941.

35. Sarkar, C., Kumar, V. and Sinha, V., Massive emissions of carcinogenic benzenoids from paddy residue burning in North India. Curr. Sci., 2013, 104(12), 1703-1709.

36. Mellouki, A., Wallington, T. J. and Chen, J., Atmospheric chemistry of oxygenated volatile organic compounds: impacts on air quality and climate. Chem. Rev., 2015, 115, 3984-4014.

37. Volkamer, R. et al., OH-initiated oxidation of benzene. Part I. Phenol formation under atmospheric conditions. Phys. Chem. Chem. Phys., 2002, 4, 1598-1610.

ACKNOWLEDGEMENTS. We thank the Director, Indian Institute of Tropical Meteorology (IITM), Pune; Director General, India Meteorological Department, New Delhi; Director, Indian Agricultural Research Institute, New Delhi, and Director, Indian Institute of Science Education and Research (IISER) Mohali for their encouragement and support during WIFEX; the Ministry of Earth Sciences, Government of India; (MoES), Savitribai Phule University, Pune, and Balloon Facility, TIFR, Hyderabad for support throughout the campaign and Grandhi Mallikarjuna Rao (G.M.R.) group and Airports Authority of India (AAI) for providing logistic support and cooperation to conduct the experiment inside IGIA, New Delhi; Several of the instruments used for this campaign have been procured under the CAIPEEX program funded by MoES. We also thank IMD for providing satellite images and synoptic charts; MODIS satellite images for public access used in this study; Shri Anand Sharma (IMD), and Dr S. D. Singh, Dr H. Pathak and Dr A. Bhatia (IARI) for their support; Astra Microwave Products Private Limited, Hyderabad for providing the wind profiler system through an MoU with IITM; and Droplet Measurement Technology (DMT, Inc.) and Dr Duncan Axisa (NCAR) for key advice on the cloud droplet probe and timely help. Some of the data analysis was performed using the IGOR (v6.10A) software interactive data analysis tool developed by Dr Vijay P. Kanawade, University of Hyderabad.

Received 16 August 2016; revised accepted 30 September 2016

doi: $10.18520 / \mathrm{cs} / \mathrm{v} 112 / \mathrm{i} 04 / 767-784$ 